M. E. Gettings

Open-File Report 85-26

Prepared for the Ministry of Petroleum and Mineral Resources, Deputy Ministry for Mineral Resources, Jiddah, Kingdom of Saudi Arabia

This report is preliminary and has not been reviewed for conformity with U.S. Geological Survey editorial standards and stratigraphic nomenclature.

If U.S. Geological Survey, Reston, VA 


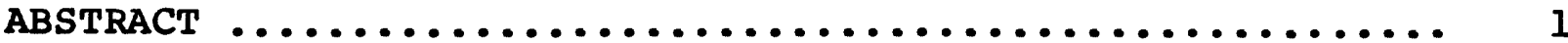

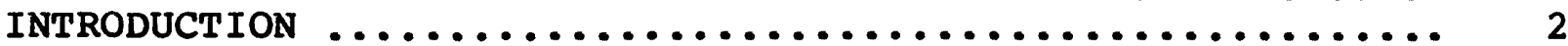

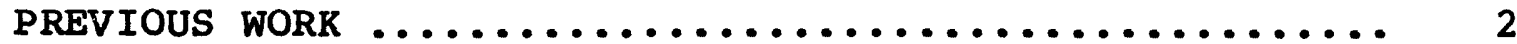

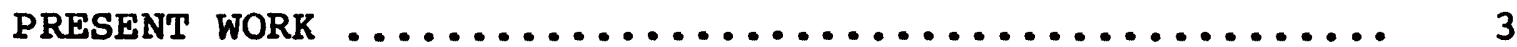

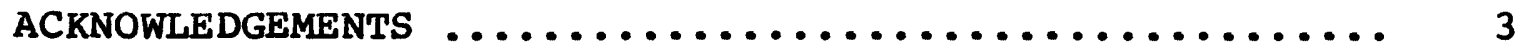

GRAVIMETER CALIBRATION AND INTERNATIONAL TIES ............ 3

GRAVIMETER CALIBRATION LINE FROM JIDDAH TO AT TA'IF ...... 11

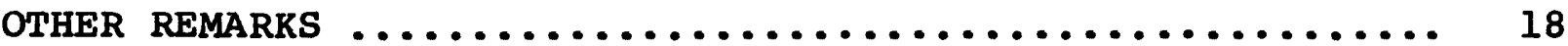

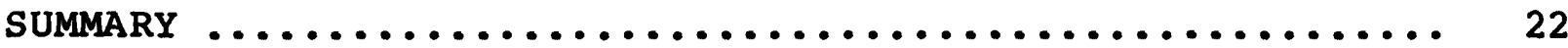

REFERENCES CITED .................................. 23

\section{FIGURES}

Figure 1. Flight path map showing planned and completed flight legs and chronological sequence of station occupations ..........................

2. Drift curves for the Lacoste-Romberg gravimeters G328, G330, G506, and G511 during the base tie and gravimeter calibration loop .............

3. Calibration factor determination plots for Lacoste-Romberg gravimeters G328, G330, G506, and

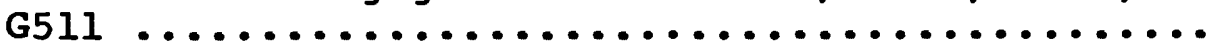

4. Scatterplots of the estimates of Jiddah gravity base station USGS $x$, before and after correction for gravimeter drift .....................

5. Map showing the location of the gravimeter

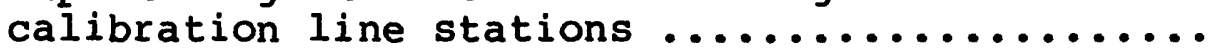

6. Cumulative gravimeter drift for Lacoste-Romberg gravimeters G328, G330, G506, and G511 during the establishment of the gravimeter calibration line

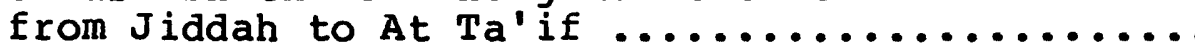

7. Plots of differences for calibration factor determination, showing the effect of gravimeter drift 
Table 1. Flight legs and stations occupied in the gravimeter base tie loop to IGNS7I stations .....

2. Calibration factors for Lacoste-Romberg gravimeters G328, G330, G506, and G511

3. Criteria used by USGS to evaluate the quality of gravity base stations established by ties to

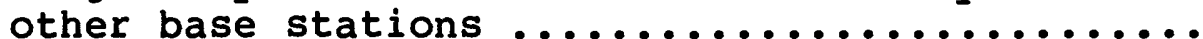

4. Principal facts for Jiddah gravity base stations and the calibration line stations ........... 17

5. Principal facts for the gravity base station network of Flanigan and Arkhrass (1972) readjusted to the IGSN71 datum .............. 20

\section{APPENDICES}

Appendix 1. Summary results for the gravimeter calibration and base tie loop from Jiddah to three IGSN7l

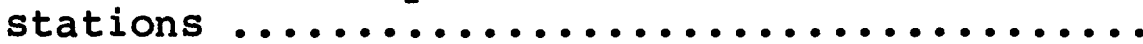

2. Station location descriptions for the gravimeter calibration line stations, and

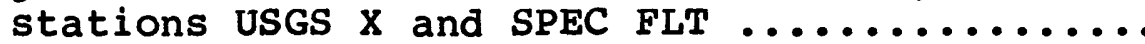




\title{
GRAVITY TIES AND GRAVIMETER CALIBRATION LINE IN WESTERN SAUDI ARABIA
}

\author{
by \\ Mark E. Gettingsl/
}

ABSTRACT

A gravity base station tie and gravimeter calibration loop was completed in June, 1980, between Jiddah and International Gravity Standardization Net 1971 (IGSN71) stations Port Sudan $\mathrm{K}$, Khartoum $\mathrm{K}$, and Nairobi B, using chartered aircraft. A gravimeter calibration, consisting of the Jiddah gravity base station and five stations along the highway to the top of the escarpment near At Ta'if, was established in March, 1980. Lacoste-Romberg gravimeters G328, G330, G506, and G51l were used for both phases of the work. Use of these stations to calibrate gravimeters for future gravity surveys in the Kingdom of Saudi Arabia will ensure uniformity of scale and that all gravity data is on the IGSN7l datum.

Analyses of the data collected have resulted in an observed gravity value for the Jiddah base station USGS $X$ of $978,738.973$ milligals (mgals) with a standard deviation of $0.024 \mathrm{mgal}$ and a standard error of the mean of 0.003 mgal for 60 out of 64 possible ties to the IGSN71. By USGS criteria, USGS $X$ is a firstorder gravity base station with a minimum accuracy of \pm 0.020 mgal. The calibration line station observed gravities are all of second-order quality or better, and the line has a range of observed gravities of approximately $504 \mathrm{mgal}$ which falls in the middle of the range of observed gravities in Saudi Arabia.

Calibration factors have been well established for the four gravimeters used in this work. Repeat observations at some of the stations of a base network reported in a previous study have been used to adjust that network to the IGSN7l datum and scale.

1/ U.S. Geological Survey, Reston, Virginia 22092, U.S.A. 


\section{INTRODUCTION}

The objective of the work described in this report is to establish a gravity base station in Jiddah, USGS $X$, and $a$ gravimeter calibration loop connected to the International Gravity Standardization Net 1971 (IGSN71) at Port Sudan, Khartoum, and Nairobi, as part of a program to compile and interpret a Bouger anomaly map of the Kingdom of Saudi Arabia. The required survey work used gravimeters, which measure only relative changes in the gravitational rather than absolute values, since absolute gravity measurements are time-consuming, costly, and require extensive instrumentation. In order to make gravity data acquired by this method comparable between survey blocks and with international gravity network measurements, the gravimeters used must be calibrated by observations at existing stations of known absolute gravity values. This procedure brings the surveyed blocks to a common datum and calibrates the scales of the gravimeters used to the value of the internationally accepted unit of gravity, the milligal (mgal).

The common practice in a country such as Saudi Arabia, where no international network stations exist, is to complete with several gravimeters one or more loops which include several stations of the international network. Further ties to the network, which are expensive and logistically difficult, are minimized if the tie is of high quality. A set of high quality stations across a gravity range of approximately 500 mgal or more, if established at the same time, can form a calibration line against which gravimeters and meters used for subsequent work can easily be calibrated to ensure uniformity of scale and datum.

\section{Previous work}

The first gravity base stations in the Kingdom of Saudi Arabia were established by AI Ghalayini (1958), using worden gravimeters. Later, Flanigan and Akhrass(1972, datach) established a base network of 42 base stations throughout saudi Arabia, using uncalibrated Lacoste-Romberg gravimeters. The primary base for each of these surveys was located at two separate places at old Jiddah International Airport, and both stations subsequently have been destroyed. The adoption in 1971 of a new datum and network (Morelli and others, 1971), referred to as the International Gravity Standardization Net 1971 (IGSN71), also necessitated a new tie to re-establish the gravity datum for Saudi Arabia. Ties to IGSN7l are reported to have been made during work in the early $1970^{\prime}$ 's by the Aerial Survey Department of the Saudi Arabian Ministry of Petroleum and Mineral Resources (V.F.Spies, written communication, 1974), but the data have never been released. 
A calibration line was established by M.E.Gettings and A.V. Shephard during the period 23-29 March, 1980, using four LacosteRomberg gravimeters in five separate runs. The tie to the IGSN7I was completed by Gettings and Abdul Rahman Kinkar of the Directorate General for Mineral Resources, during the period 19-25 June, 1980, using the same instruments and a chartered aircraft from Saudi Arabian Airlines. Data reduction was completed by Gettings. About three man-months of professional time were required for planning, data acquisition and reduction, and report writing.

\section{Acknowledgments}

The work was completed in partial fulfilment of a work agreement between the Deputy Ministry for Mineral Resources, Kingdom of Saudi Arabia, and the U.S. Geological Survey. The assistance of H.E. M.Q. Asaad, Assistant Deputy Minister for Mineral Resources, A.V. Shephard, A.R. Kinkar, and the technical staff of the Geophysics Section of the U.S. Geological Survey, Saudi Arabian Mission, is gratefully acknowledged. The flight crew (Capt. W. Viars, Capt. D. Douglass, and G. Embry) provided invaluable assistance and cheerfully flew long periods throughout the program.

\section{GRAVIMETER CALIBRATION AND INTERNATIONAL BASE TIES}

Planned and actual flight legs carried out in the period 19-25 June, 1980, are shown in figure 1. Lacoste-Romberg gravimeters G328, G330, G506, and G51l were used, and were transported in their padded cases strapped to the aircraft floor on pads. Aircraft-type antivibration mounts would have been desirable to minimize vibration-induced gravimeter drift (Hamilton and Brule, 1967), but one only was available, for gravimeter G330. Flight conditions generally were good, except for leg E (fig. 1) where turbulence from local thunderstorms between Juba, sudan, and Nairobi, Kenya, caused several meters to experience tares (discussed below).

Security problems at Cairo Airport precluded reading the meters at station Cairo $N$, and the Cairo leg was abandoned. Ties were completed at IGSN7l stations Port Sudan $K$, Khartoum $K$, and Nairobi B, for a total of 16 one-way ties with four gravimeters, to Jiddah base station USGS $x$, resulting in 64 one-way ties. Flight legs and stations occupied are summarized in table 1. An excenter station SPEC FLT, a nearby station established at the Special Flight hangar at the old International Airport, Jiddah, was also tied into the loop to back up the primary base station. 


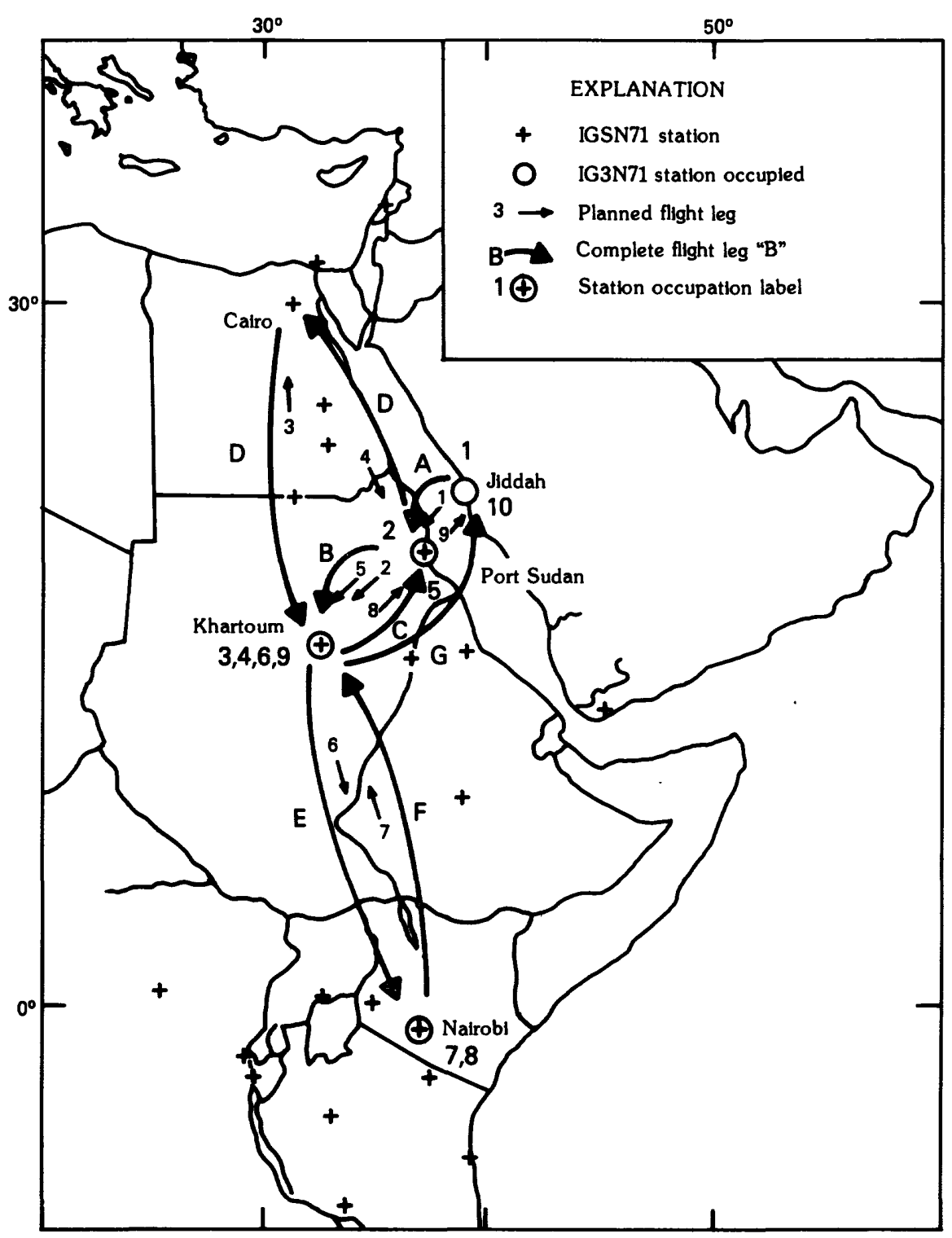

Figure 1.--Flight path map showing planned and completed flight legs and chronological sequence of station occupations. The open circle symbol denotes stations of the base tie and gravimeter calibration loop. The symbol "+" denotes a station of the International Gravity Standardization Net 1971 (IGSN71). 
Table 1. -Flight legs and stations occupied in the gravity base tie loop to IGSN7l stations. Air times are time fran takeoff to landing and are GMT +3.

\begin{tabular}{|c|c|c|c|c|c|}
\hline Leg & Route & Date & Air times & Stations occupied & Remarks \\
\hline A & Jiddah-Port Sudan & 20 June & 0930-1030 & $\begin{array}{l}\text { USGS } x \text {, SPEC FLT, } \\
\text { PT SDN } K\end{array}$ & \\
\hline B & Port Sudan-Khartoum & 20 June & $1206-1400$ & PT SDN K, KHART K & \\
\hline C & Khartoum-Port Sudan & 21 June & $1030-1238$ & KHART K, PT SDN K & \\
\hline D & $\begin{array}{l}\text { Port Sudan-Cairo- } \\
\text { Khartoum }\end{array}$ & 21 June & $1339-2345$ & PT SDN $K$, HART $K$ & $\begin{array}{l}\text { Time includes ground } \\
\text { time in Cairo }\end{array}$ \\
\hline $\mathbf{E}$ & Khar toum-Juba-Nairobi & 22 June & $1136-1842$ & KHART K, NAIR B & $\begin{array}{l}\text { Turbulence Juba-Nai robi, } \\
\text { refuel in Juba }\end{array}$ \\
\hline $\mathbf{F}$ & Nairobi-Juba-Khartoum & 23 June & $1054-1803$ & NAIR B, KHARI K & $\begin{array}{l}\text { Light turbulence } \\
\text { Nairobi-Juba, refuel. } \\
\text { in Juba }\end{array}$ \\
\hline G & Khartoum-Jiddah & 23 June & $1905-2148$ & $\begin{array}{l}\text { KHART } K \text {, SPEC FLT, } \\
\text { USGS } \mathrm{X}\end{array}$ & \\
\hline
\end{tabular}

Table 2.--Calibration factors for Lacoste-Romberg gravimeters G328, G330, G506, and G511. The column labeled "preliminary factor" is based only on the calibration on IGSN7l stations Port Sudan $K$, Khartoum $K$ and Nairobi $B$. The column labeled "final factor" is based on a refinement of the factors using the five runs on the calibration line from Jiddah to At Taif (see text for details).

\begin{tabular}{cccc} 
Gravimeter & Preliminary factor & Final factor & Standard deviation \\
\hline G328 & 1.00099 & 1.00086 & 0.00007 \\
G330 & 1.00030 & 1.00030 & 0.00002 \\
G506 & 1.00041 & 1.00041 & 0.00006 \\
G511 & 1.00044 & 1.00044 & 0.00005
\end{tabular}


Each gravimeter was read at least twice at each station, and if inconsistent readings were obtained, that is if successive readings differed by more than 0.005 dial division, readings were continued until consistency was obtained. All gravimeters were we11-behaved, and more than two readings per meter at a station were seldom necesary. Generally one hour or more elapsed after arrival at a station before readings were taken.

The calibration factor for a given gravimeter is defined as follows: For a particular gravimeter and a complete calibration loop there is a resulting set of gravimeter readings, $\mathrm{MR}_{i}(i=1$, 2 , ..., $n)$, where the subscript $i$ refers to the gravimeter reading at station $i$ of the $n$ stations of the 100p, that is, after different legs of tie loop, the readings are considered as if each reoccupation was a separate station. The reading set is converted to an equivalent set of values in mgals according to the gravimeter manufacturer's conversion tables, and corrections for earth tides (Longman, 1959) are applied, yielding a set of readings, $R_{i}(i=1,2, \ldots, n)$. For each station, the true observed gravity is

where

$$
\begin{aligned}
g_{i} & =g_{m, i}+\delta, \\
g_{m, i} & =g_{j}+\left(R_{i}-R_{j}\right),
\end{aligned}
$$

and $\delta$ is the difference between the true observed gravity and the measured observed gravity $\mathrm{g}_{\mathrm{m}}, \mathrm{g}_{\mathrm{j}}$ is the true observed gravity of the base station chosen for estimating the observed gravity at station $i$, and $R_{i}$ and $R_{j}$ are the gravity meter readings in mgals at stations $i$ and $j$ respectively, as defined above. It is assumed that the difference can be represented as a function of the true observed gravity. Then:

$$
g_{i}=g_{j}+\left(R_{i}-R_{j}\right)+\delta\left(g_{i}\right)-\delta\left(g_{j}\right) \text {. }
$$

A linear model for the difference $\delta$ is generally assumed for Lacoste-Romberg meters:

$$
\delta(g)=\delta_{0}+m g,
$$

where $\delta_{0}$ is the intercept at $g=0$, and $m$ is the (1inear) slope.

Then

and $\quad \begin{aligned} & g_{i}=g_{j}+\left(R_{i}-R_{j}\right)+\delta_{0}+m_{j}-\delta_{i}-\delta_{0}-m_{j} \\ & \left.g_{i}=\left(R_{i}-R_{j}\right)+g_{j}-g_{j}\right)\end{aligned}$

Rearranging the terms gives

or

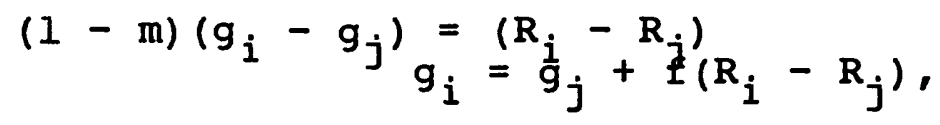


where $f=1 /(1-m)$ is defined as the calibration factor. The calibration correction is a factor, so it can be applied when the gravimeter reading is converted to mgal, that is, $R_{i}^{\prime}=f x$ $\mathrm{MR}_{i}$ (mgal).

A difference can be calculated for each pair of readings in the loop, since the true observed gravity is known at all the base stations. All possible differences are considered without regard to the order in which the stations are read. The differences between measured and true observed gravity at each station are plotted as a function of observed gravity. A good indication of the gravity drift can be obtained from the scatter in the differences at each station by plotting all possible combinations, including reoccupations of the same station. Drift corrections can be incorporated before plotting the differences, but seldom are necessary and may be misleading since the LacosteRomberg gravimeters seldom show steady drift on individual short ties as are used here; rather they tend to drift by sudden jumps or "tares" which are difficult to correct for in any case. A straight line is then fitted to the differences, usually manually because discrepant points can then be given less weight. The slope of the line $m$ gives the desired calibration factor $1 /(1-m)$.

Gravity differences between the known stations and the unknown ones (in this case, USGS $X$, and SPEC FLT) can be determined once the gravimeter calibration factors have been determined from the known stations in the loop. The values of observed gravity at the new station is calculated from weighted averages of all available estimates from all known bases occupied in the loop of the observed gravity at the new station. In this case it is usually desirable to incorporate a correction for gravimeter drift since the time-lapse between some legs of the loop are usually long enough for significant drift to occur, and drift correction significantly reduces the dispersion of the observed gravity estimates at the new station. A computer program was written to process the data into a form which provides tables of the required differences, in order to facilitate data reduction and minimize errors. The program flow is as follows: The multiple readings for each gravimeter during one occupation of a station are converted to mgal, the tidal correction applied, and the time of the reading, in days since 1200 hours, 31 Dec., 1899. is computed. The readings are then averaged to give an average time, average meter reading in mgal, and an estimate of the standard deviation of the meter reading for each gravimeter for each station occupation. Next, the user specifies two station names and times to be used as the starting and ending base of the loop or any portion of it. As many sets of names and times can be specified as are needed to obtain all the required measured observed gravities. A table giving the name, elapsed time, mgal differences, measured observed gravity, difference 
between measured and true observed gravity, and successive difference between stations relative to the starting and ending bases is produced for each set. Finally, a table of gravimeter drift information for each gravimeter is produced which lists the time, drift since last occupation, cumulative drift, estimates of the standard deviation of the drifts, and drift rate for all reoccupations of each base station for each gravimeter.

Summary tables of the calibration loop results for each of the four meters used in this survey are given in appendix 1 . Drift curves for each gravimeter are plotted as a function of time using the cumulative drift information from reoccupations of loop stations. A total drift curve is produced by combining the drift segments for each station by some specified procedure. Some model must be assumed in order to fit the various segments together, since the drift is unknown between different base stations. The technique applied in this report is to use the outermost segment as a start, and fit successively smaller inner segments to the curve. The philosophy followed in fitting segments is to keep the curve as smooth as possible and minimize the number of changes of sign of the slope. If there is no indication as to how a segment should be positioned, its drift is positioned on the linear trend defined by the next bracketing segment. This technique is illustrated in the plot for gravimeter G330 in figure 2. The drift curves for meters G328, G506, and G511 and also shown in the same diagram.

The final observed gravity base value at usGs $x$ was calculated by averaging all possible one-way ties to the IGsN7l stations. No drift correction was made in the first case. A one-way tie is defined as one occupation of a known station and one occupation of the station whose observed gravity is unknown. One-way ties for the loop reported here have 16 possibilities, as follows; The ties for the Port Sudan-Jiddah leg are (fig.1); 1-2, $1-5,2-10$, and 5-10; for the Khartoum- Jiddah leg, 1-3, 1-4, 1-6, $1-9,3-10,4-10,6-10, a, d$ 9-10; and for the Nairobi-Jiddah leg, $1-7,1-8,7-10$, and 8-10. A total of 64 one-way ties occur in the loop. The mean observed gravity for these data at USGS $X$ was $978,738.981 \mathrm{mgal}$, with a standard deviation of $0.104 \mathrm{mgal}$, and a standard error of the mean of $0.013 \mathrm{mgal}$. The standard error of the mean is defined as the standard deviation divided by the square root of the number on one-way ties. A statistical weighted mean (Bevington, 1969, p. 77-80) was also computed, using the elapsed time between station readings for each leg as a measure of the uncertainty in the observed gravity estimate. The resulting mean value for the onserved gravity at USGS $X$ was $978,738.970 \mathrm{mgal}$ with a standard deviation of $0.041 \mathrm{mgal}$. The 

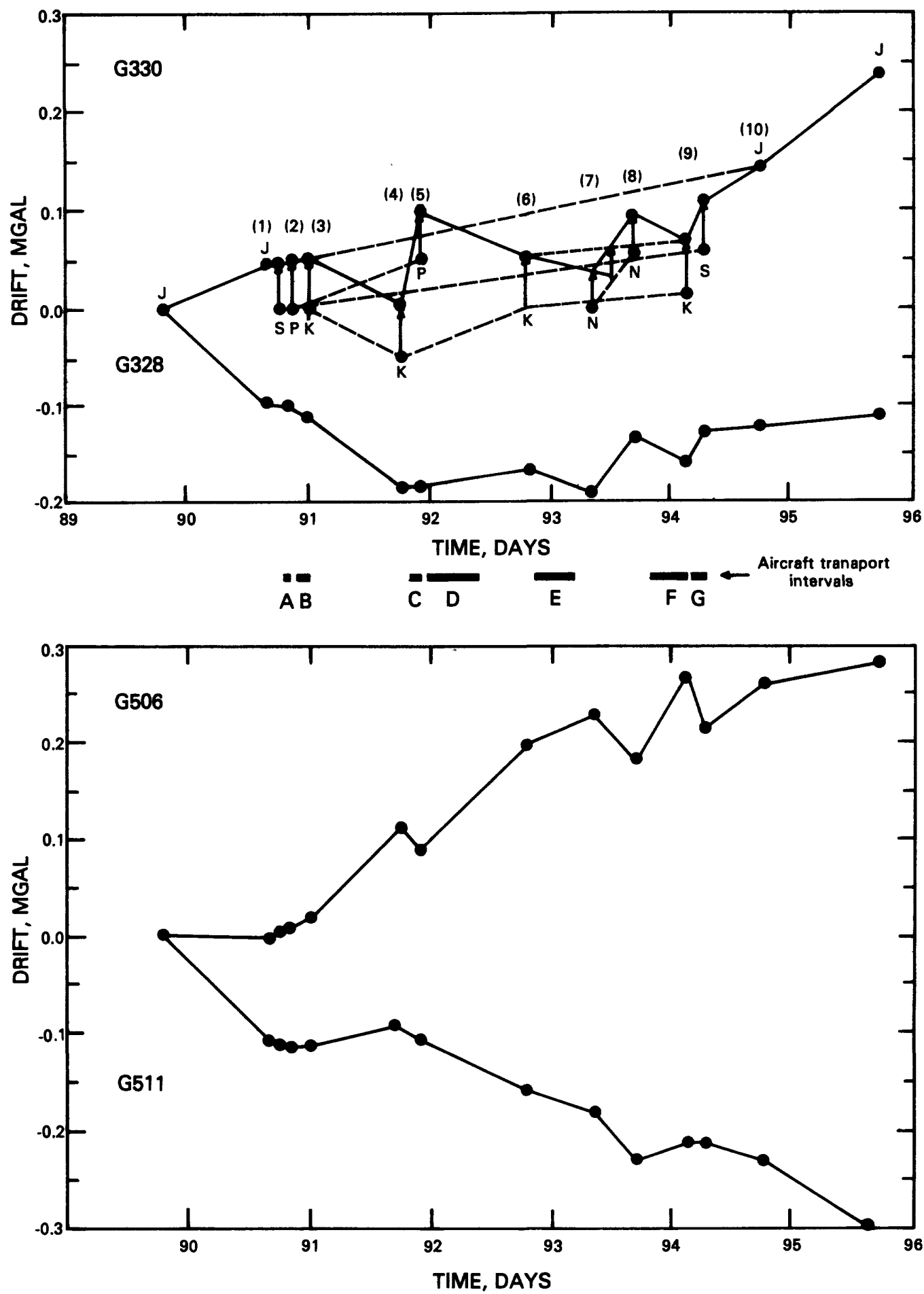

Figure 2.--Drift curves for the four LaCoste-Romberg gravimeters G328, G330, G506, and G511 during the base tie and gravimeter calibration loop. The uppermost curve, labeled "G330" shows the method of constructing the curve from drift observations at recognized base stations other than the station at which the loop was begun and finished. Station designations are: J, Jiddah USGSX (beginning and ending point of the station); S, station SPEC FLT; P, Port Sudan K; K, Khartoum K; and N, Nairobi B. Note that the midpoint of the Nairobi drift segment is arbitrarily put at the midpoint of the bracketing Khartoum drift segments (short-dashed line) in the absence of other controlling drift information. Solid horizontal bars between the two middle curves indicate times of gravimeter transport in aircraft. 

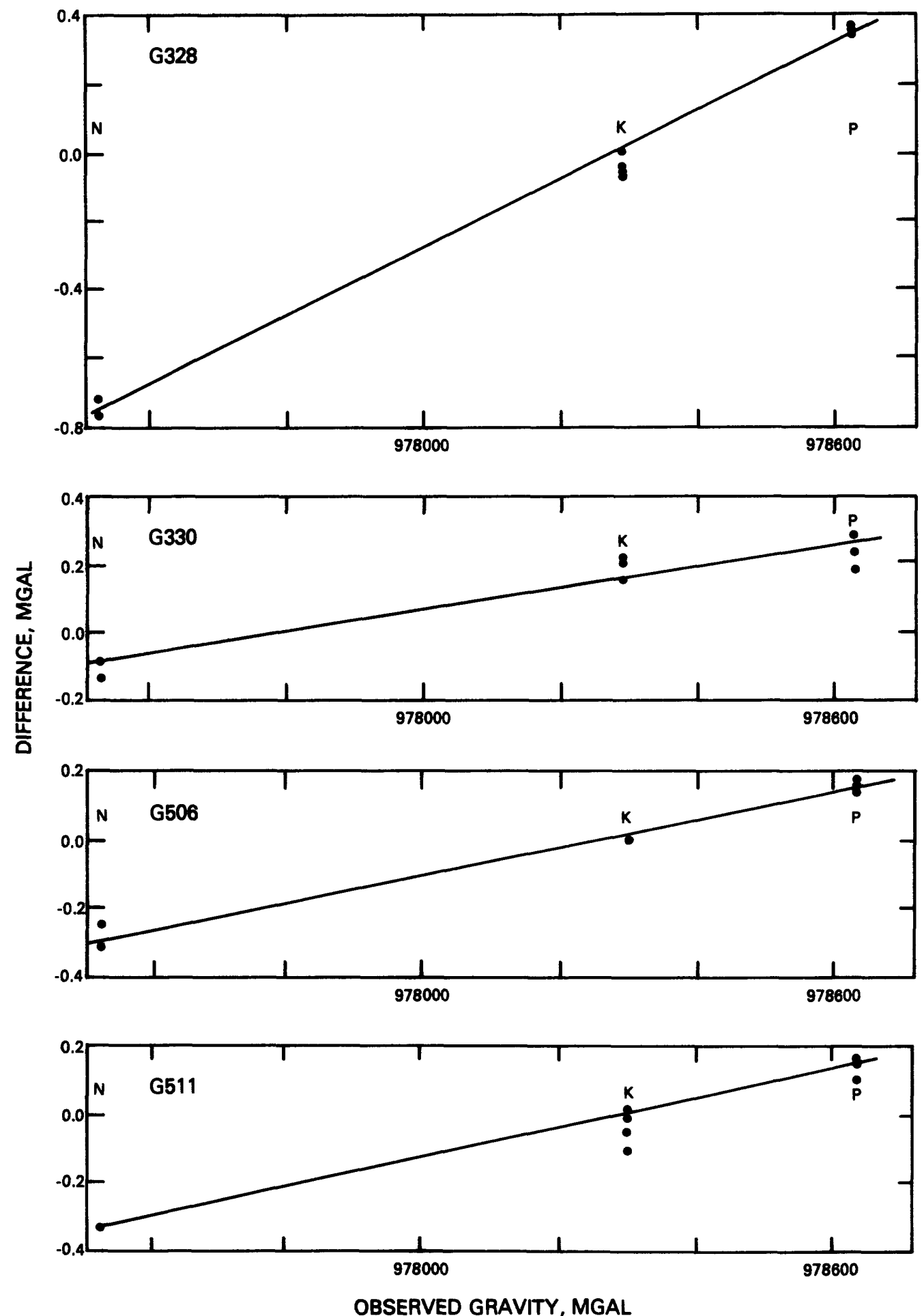

Figure 3.--Calibration factor determination plots for Lacoste-Romberg gravimeters G328, G330, G506, and G511. The plotted difference is the true observed gravity at the station minus the value measured by the gravimeter relative to Khartoum $K$ base value. The slope $(\mathrm{m})$ of the indicated fitted line gives the calibration factor $f=1 /(1-m)$. Station designations are: $N$, Nairobi $B ; K$, Khartoum $K$; and $P$, Port Sudan K. Values plotted for $G 506$ were corrected to reduce scatter from drift. 
distribution of observed gravity estimates for USGS $x$ for the four meters is shown in figure $4(\mathrm{~A})$. Drift corrections using the curves of figure 2, were then applied to the set of one-way ties and the resulting distribution of observed gravity estimates at USGS $X$ is shown in figure 4 (B). The mean value of these estimates is $978,738.969 \mathrm{mgal}$ with a standard deviation of $0.029 \mathrm{mgal}$ and a standard error of the mean of 0.004. Examination of figure 4 (B) shows one obvious tare, that is, for gravimeter 6328 on the Nairobi leg. Deleting these four ties from the data yielded a mean observed gravity at USGS X, Jiddah, of 978,738.973 mgal with a standard deviation of $0.024 \mathrm{mgal}$ and a standard error of 0.003 mgal for the 60 one-way ties. This value is the accepted final value of observed gravity for Jiddah USGS X base gravity station.

The quality of the USGS $x$ observed gravity value was evaluated according to criteria established by UsGs for gravity survey work in the United States (Robbins, 1971). These criteria are summarized in table 3. In the evaluation of station observed gravity quality, the estimated standard deviation, standard error of the mean, the number of ties used in the mean, the number of ties used relative to the total number of ties made, the number of ties to different base stations, and the number of gravity meters used are all considered. The quality of the base stations on which the new station is based must also be considered. Four classes of quality are defined in this scheme (table 3): Prime. first order, second order, and third order. The base stations used were evaluated by these criteria and classed as follows: Khartoum K, prime; Port Sudan K, first order; and Nairobi B, second order. By the criteria of table 3, the gravity tie to Jiddah station USGS $X$ is a prime tie, and the observed gravity value is judged to be first order with a minimum accuracy of \pm $0.020 \mathrm{mgal}$.

\section{GRAVITY CALIBRATION LINE FROM JIDDAH TO AT TA'IF}

A gravity calibration line from USGS $x$ gravity base station at $J$ iddah to the top of the escarpment near At Ta'if, comprising six stations at gravity intervals of approximately $100 \mathrm{mgal}$, was established to monitor changes in calibration of the four meters used, and to conveniently calibrate additional meters as required in the future.

The stations were established in five-ladder-sequence (A-B-C station locations are shown in figure 5, and detailed descriptions of the individual sites are given in appendix 2. The data were reduced using the computer program described above, and drift curves for each of the gravimeters are shown in figure 6 . After correcting for drift, the measured gravity differences between the successive stations were averaged for each meter, and 


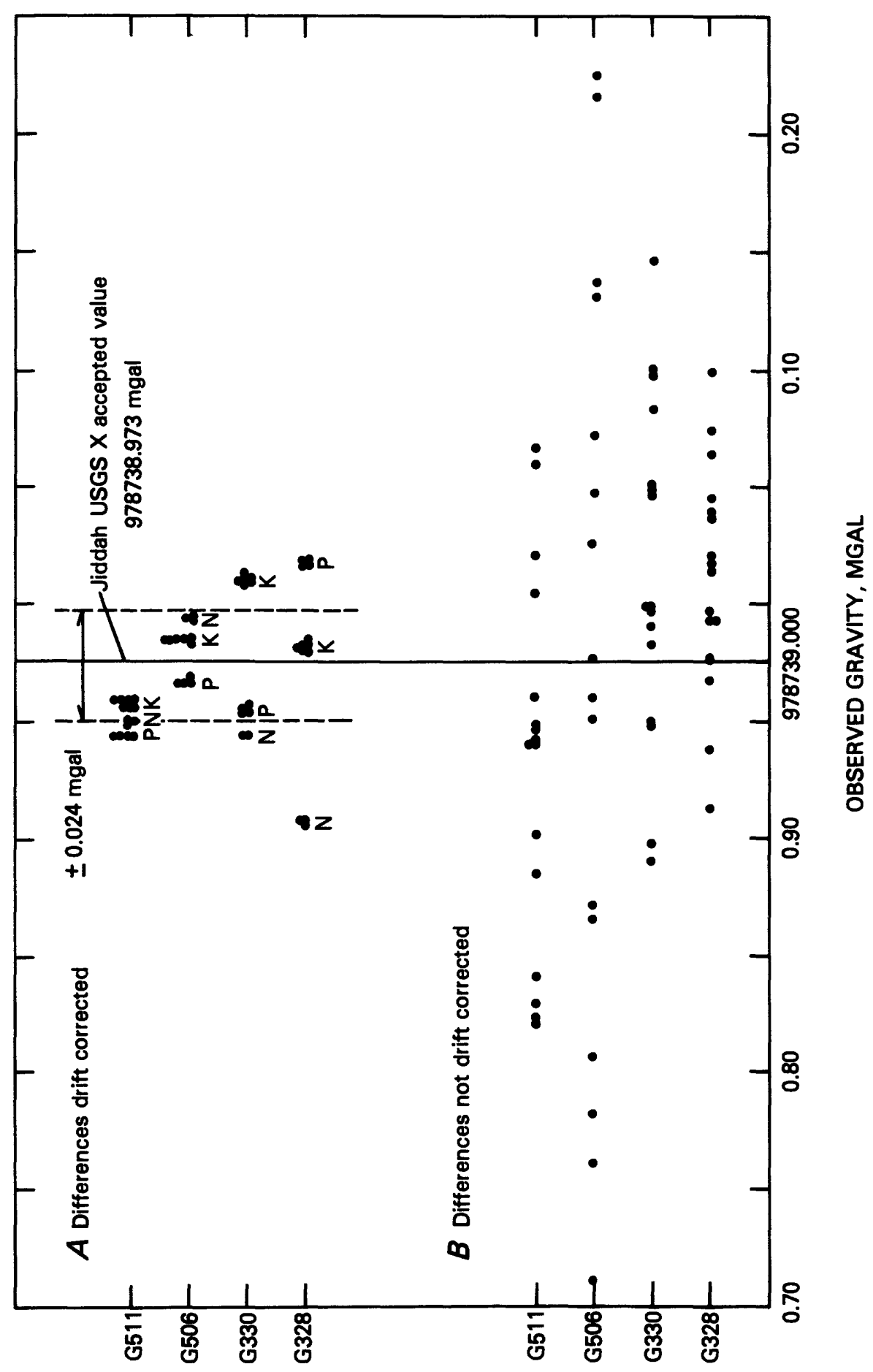

近

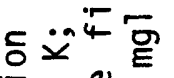

氙 동푱

¿

نे

员苋

능.

4ลํำ

$\ddot{0}$

車

$5>0$

뜬원

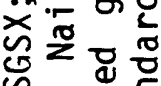

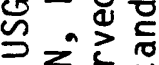

已过芯

.디융

氠

ᄃ

뵤요

范范

ธธ㇒์

ज的的

ते पे

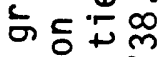

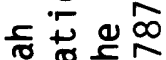

꿍ㅎㅀ

$5.5^{\circ}$

능동 정

苟氙

ג团

苋这芯。

.

药

电艺告

造它

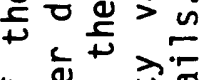

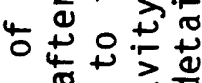

ro

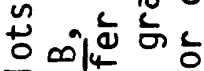

ए...

ब苾

出乐文离

ช

น 틍요

1 व

눙잉

$+E \Phi+$

II $=\underline{1}$

志台垈

4 


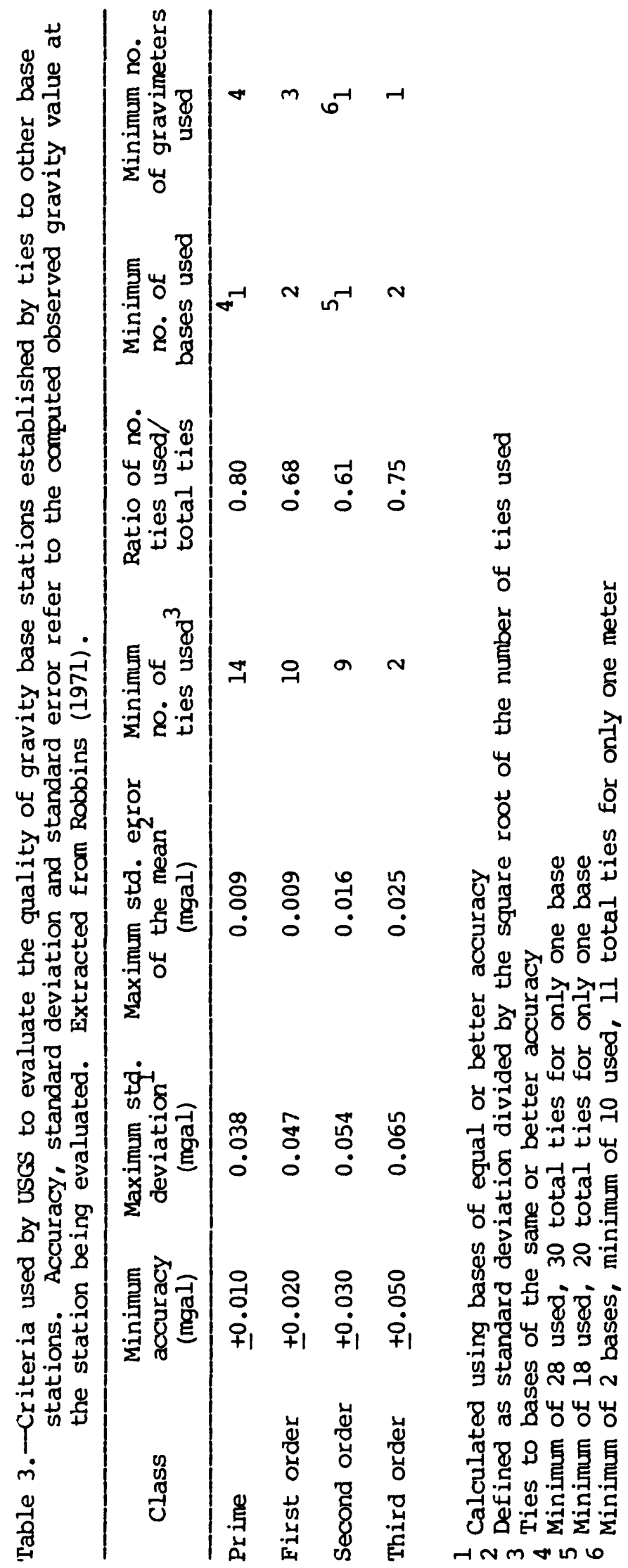




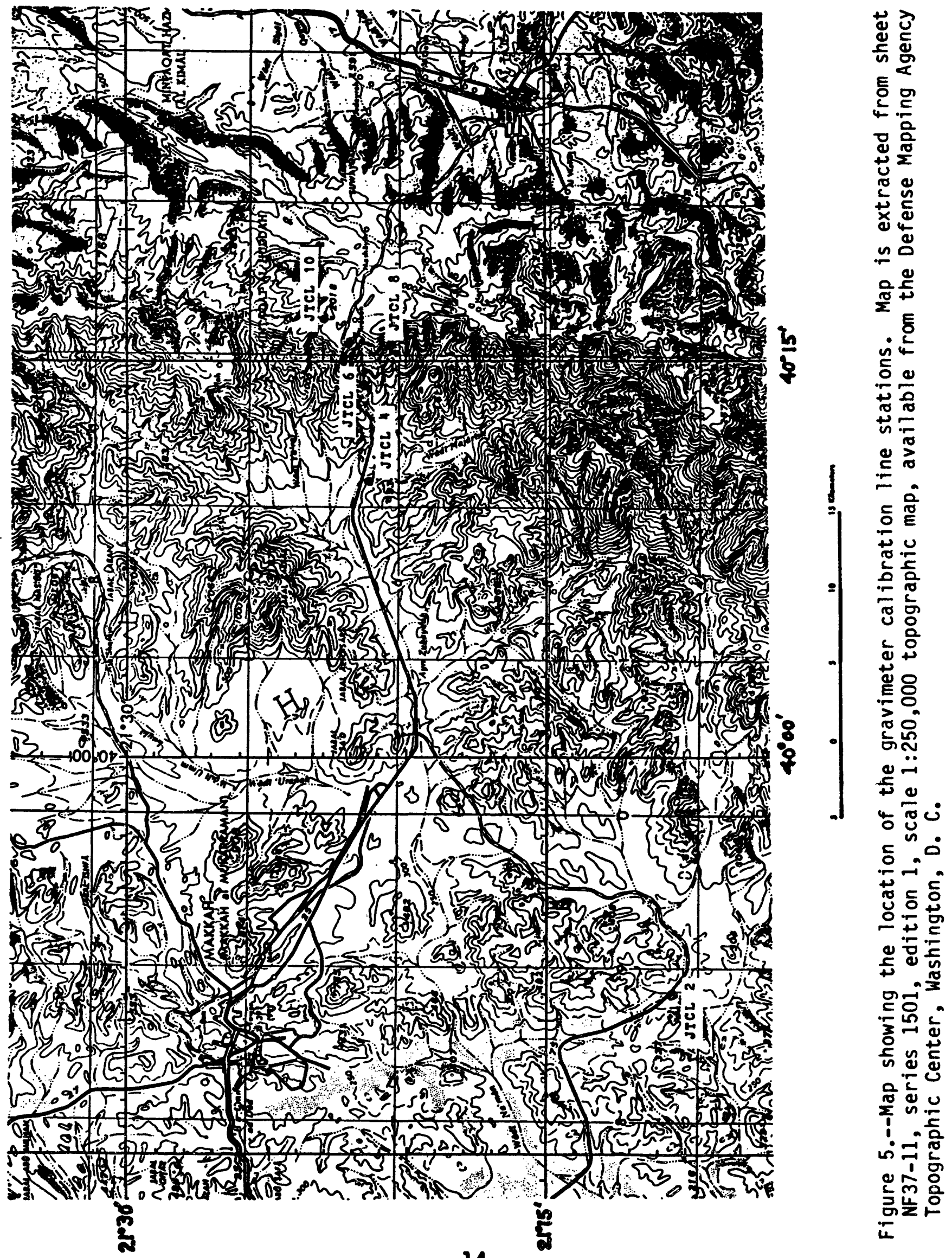



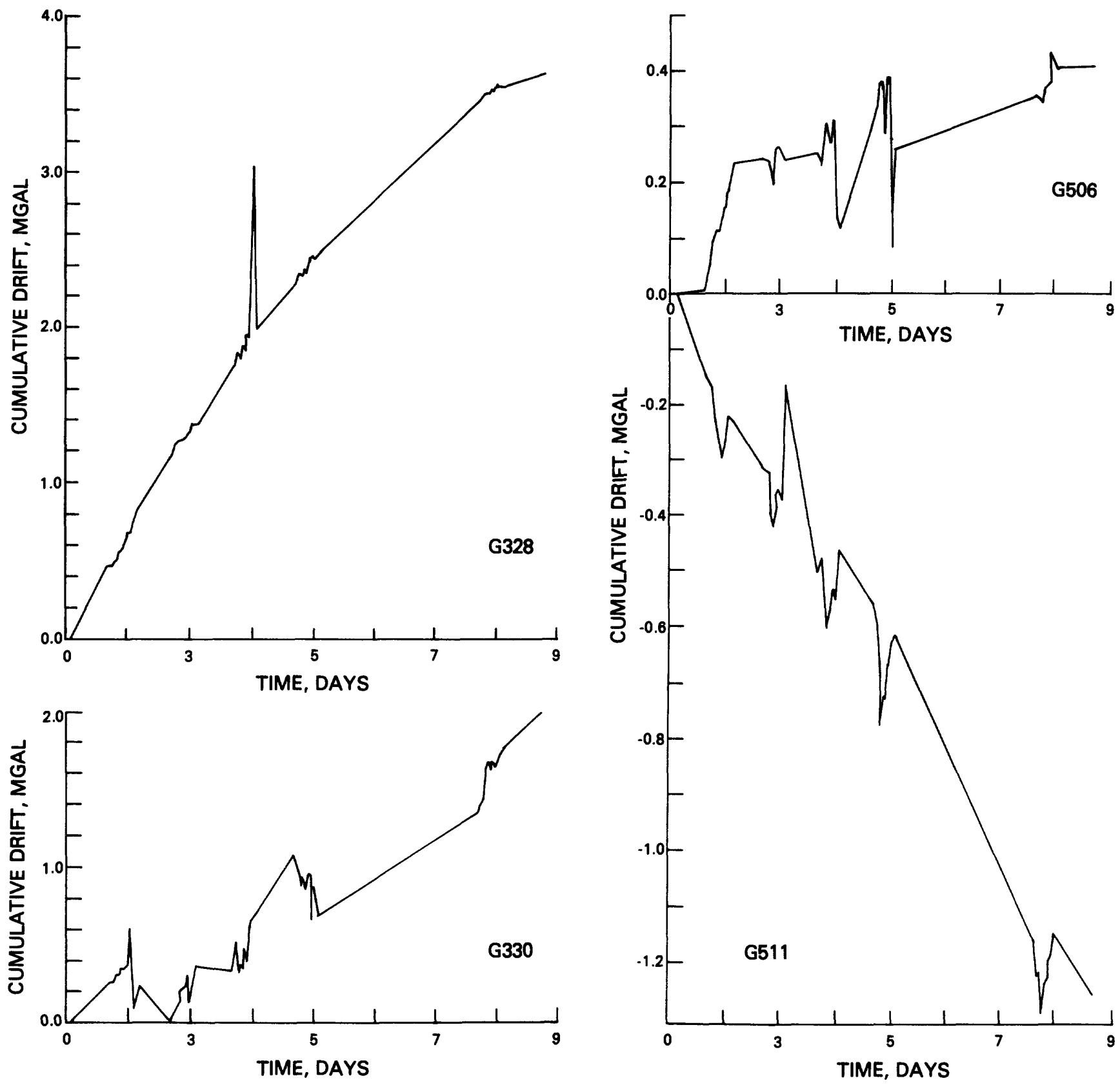

Figure 6.--Cumulative gravimeter drift for Lacoste-Romberg gravimeters G328, G330, G506, and G511 during the establishment of the gravimeter calibration line from Jiddah to Al Taif. Note the different ordinate scale for meter G328. Curves were constructed by the method illustrated in figure 2 . 
observed gravity at each station was calculated using the preliminary calibration factors obtained from the IGSN71 calibration. The principal facts for the station are given in table 4.The station altitudes in table 4 (other than USGS $X$ ) were determined by altimetry and may contain large errors. For calibration work, however, station altitude is only needed for the earth tide calculations, which are only weakly dependent on altitude, so that approximate station altitudes are sufficient.

The final step was to rerun the computer reduction of the calibration line data with the observed gravity at each station treated as a known quantity. Then, for each of the 20 runs, measured versus true observed gravity differences were plotted against observed gravity as described for the IGSN71 stations above. These plots were used to estimate the gravimeter calibration factor, and averages of the factor for the five runs on the calibration line plus the IGSN71 calibration loop for each meter yielded the final calibration factor value, shown in table 3.

To show how the calibration line data are used to refine the gravimeter calibration factors, consider the difference between the true and measured observed gravities at a station $\delta$ to be given by

$$
\delta(g)=\delta_{0}+\mathrm{mg}+\epsilon
$$

where $\epsilon$ is the gravity drift, and the other symbols are as previously defined. Then the true observed gravity is

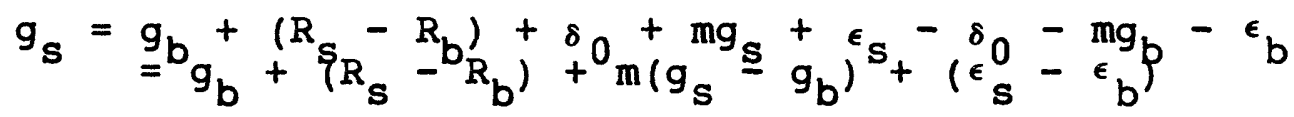

where the subscript $s$ denotes a quantity at the station, and the subscript $b$ refers to one at the base. Rearranging gives

$$
\left(g_{s}-g_{b}\right)-\left(R_{s}-R_{b}\right)=\delta=m\left(g_{s}-g_{b}\right)+\left(\epsilon_{s}-\epsilon_{b}\right)
$$

If the drift and the time intervals between successive stations up and down the line are approximately equal, and the drift rate is constant, the drift $\epsilon-\epsilon$ will appear to be a linear function of $g$, with slope $\mathrm{m}_{d}$, and one can write

Then

$$
\left.{ }_{\delta}{ }_{\delta} /\left(g_{s}{ }_{b}-g_{b}\right) \stackrel{m_{d}}{\left(g_{s}\right.}-g_{m}+g_{b}\right)
$$




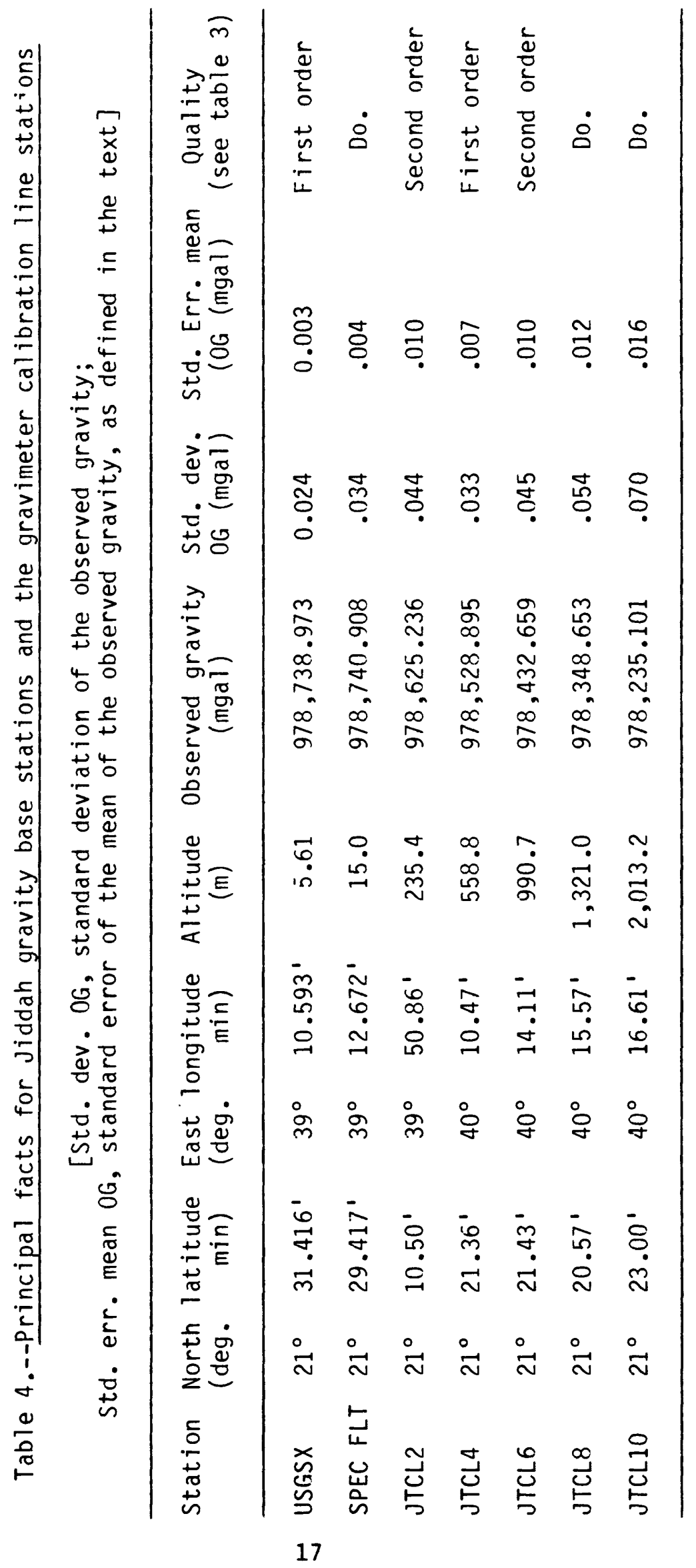


and the slope of a plot of difference $\delta$ versus observed gravity is just the algebraic sum of the calibration factor slope $m$ amd the drift rate $\mathrm{m}_{\mathrm{g}}$. The drift rate may have either sign and may change during the calibration run. The calibration factor may have either sign, depending on the gravimeter in question, but will remain constant. In order to sort out the various components, the difference is plotted for each station relative to the loop open reading for readings both up and down the line, and again using the loop close readings as the reference. This yields four sequences of differences, and three examples are shown in figure 7 .

To illustrate the analysis for these types of plots for the calibration factor, consider the case of approximately constant positive drift for the entire run (refer to the drift curve of fig. 6 for G506) which is the case for the plots of figure 7 (A). here the slope for the segment up the Iine USGS $X$ to LTCLI0) has a negative slope due to the calibration factor (difference increasing with time and thus decreasing g) and the drift has a negative slope (drift increasing with time and thus decreasing g) and so the measured slope of the line fitted to the up-line plot is $-m-m_{d}$. Coming down the line, the slope component from the drift is positive (drift increasing with time and thus g) so the slope of the fitted line is $-m+m_{d}$. Solving these two simuntaneous equations for the calibration slope gives

$$
\mathrm{m}=-(\text { slope }) / 2
$$

In practice, the slopes of the lines fitted to the up-line segments relative to loop-open and loop-close are averaged, as are the two down-line segments. Similar analysis can be performed for other types of drift behavior. Tares during the run show up on these plots as offset segments with nearly the same slope. Figures 7 (B) and 7 (C) show the cases where the drift changed sign and an obvious tare, respectively.

\section{OTHER REMARKS}

Six of the base stations of the network established by Flanigan and Akhrass(1972 dowach were reoccupied several times using the Lacoste-Romberg gravimeter G330, during regional gravity survey work in the southern Arabian shield (Gettings, 1983). The reoccupied stations were JED BASE, KGN-2, KGN-3, KGN-16, KGN-17, and KGN-18 (Flanigan and Akhrass (1972 davef). The station JED BASE was at the old Jiddah International Airport and was the primary base for the network. This station has become uncertain in altitude by an unknown amount due to repaving of the airport apron, thus a small but unknown uncertainty is present in the tie to the network. Although the two gravimeters used were Lacoste-Romberg (G50 and G62), they were uncalibrated, and so an average calibration factor was computed to adjust the Flanigan and Akhrass (19\%2, luphy values. Linear regression performed on the 

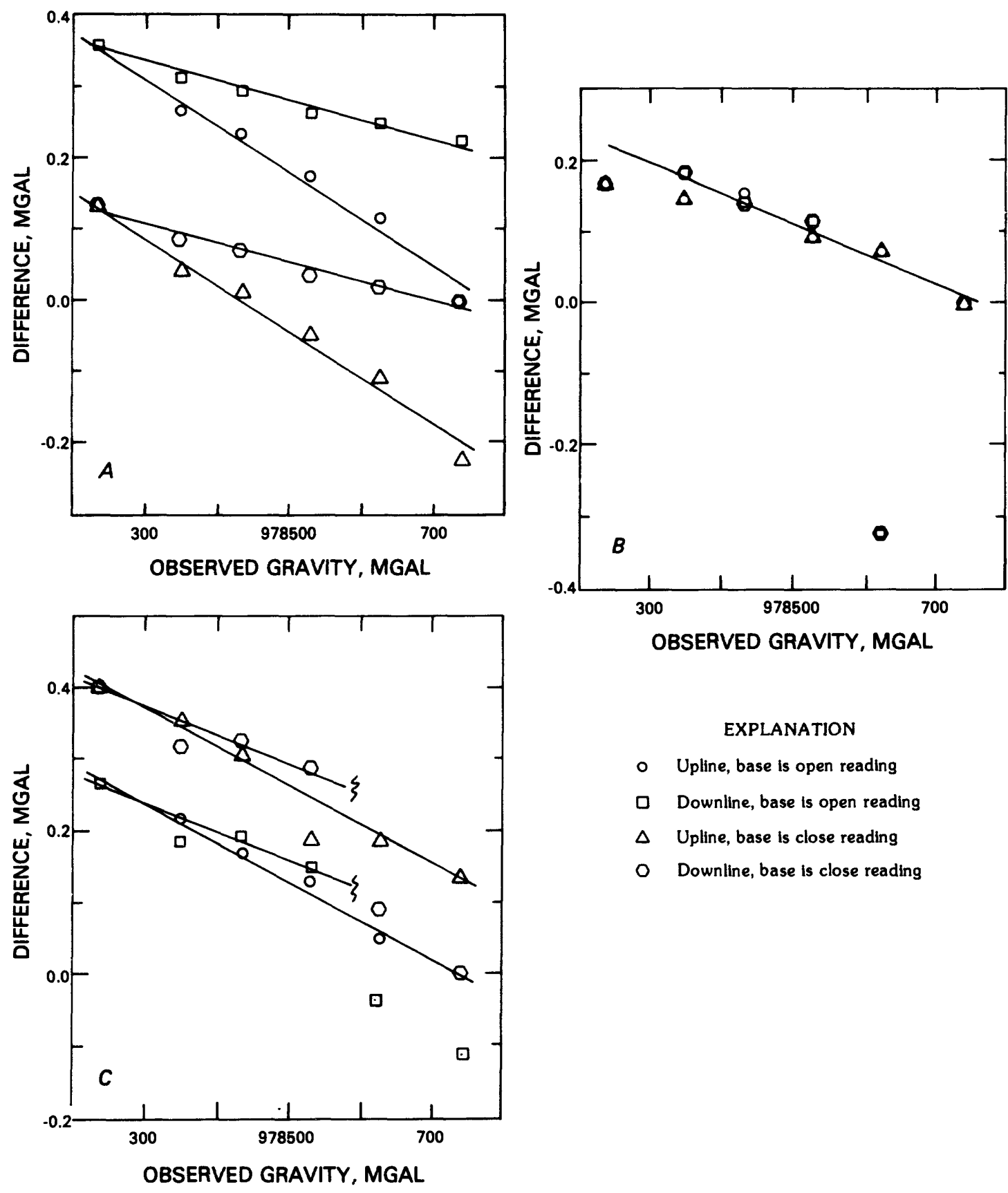

EXPLANATION

- Upline, base is open reading

$\square$ Downline, base is open reading

$\triangle$ Upline, base is close reading

- Downline, base is close reading

Figure 7.--Plots of differences for calibration factor determination, showing the effect of gravimeter drift. Plots are for gravimeter G506 during the periods 1.72.3 (A), 2.8-3.2 (B), and 3.7-4.2 (C) days on the G506 drift curve of figure 6 . "Upline" means for the part of the 10op from USGSX to JTCL10; "downline" means for the part of the loop from JTCL10 to USGSX. Open reading is the beginning reading for the loop at USGSX; close reading is the final reading for the loop at USGSX. Effect of approximately constant monofonic drift is shown in $A$, an example of a change in sign of $\mathrm{drift}$ is shown in $B$, and $C$ shows the effect of a tare in the gravimeter. See text for details. 
Table 5.--Principal facts for the gravity base station network of Flanigan and Akhrass (1972) readjusted to the IGSN71 datum

[See text for details]

\begin{tabular}{|c|c|c|c|c|c|}
\hline Station & $\begin{array}{l}\text { Latitude } \\
\text { (North) }\end{array}$ & $\begin{array}{l}\text { Longitude } \\
\text { (East) }\end{array}$ & $\begin{array}{l}\text { Altitude } \\
(\mathrm{m})\end{array}$ & $\begin{array}{c}\text { Observed } \\
\text { gravity } \\
\text { (mgal) }\end{array}$ & $\begin{array}{l}\text { Standard } \\
\text { deviation } \\
\text { (mgal) }\end{array}$ \\
\hline $\begin{array}{l}\text { JED BASE } \\
\text { KGN-2 } \\
\text { KGN-3 } \\
\text { KGN-4 } \\
\text { KGN-5 }\end{array}$ & $\begin{array}{l}21^{\circ} 30.00^{\prime} \\
18^{\circ} 43.86^{\prime} \\
20^{\circ} 09.33^{\prime} \\
21^{\circ} 33.78^{\prime} \\
23^{\circ} 30.20^{\prime}\end{array}$ & $\begin{array}{l}39^{\circ} 12.00^{\prime} \\
41^{\circ} 24.33^{\prime} \\
40^{\circ} 17.11^{\prime} \\
39^{\circ} 13.82^{\prime} \\
38^{\circ} 49.10^{\prime}\end{array}$ & $\begin{array}{r}15.24 \\
46.97 \\
8.25 \\
45.25 \\
209.50\end{array}$ & $\begin{array}{l}978,741.008 \\
978,559.055 \\
978,681.001 \\
978,749.161 \\
978,807.300\end{array}$ & $\begin{array}{l}0.080 \\
.035 \\
.034 \\
.080 \\
.050\end{array}$ \\
\hline $\begin{array}{l}\text { KGN-6 } \\
K G N-7 \\
K G N-8 \\
K G N-9 \\
K G N-10\end{array}$ & $\begin{array}{l}25^{\circ} 03.23^{\prime} \\
26^{\circ} 34.08^{\prime} \\
28^{\circ} 07.78^{\prime} \\
29^{\circ} 16.52^{\prime} \\
29^{\circ} 05.33^{\prime}\end{array}$ & $\begin{array}{l}37^{\circ} 17.07^{\prime} \\
36^{\circ} 26.85 \\
35^{\circ} 07.52^{\prime} \\
34^{\circ} 57.38^{\prime} \\
36^{\circ} 08.62^{\prime}\end{array}$ & $\begin{array}{l}133.74 \\
904.30 \\
143.30 \\
215.80 \\
864.65\end{array}$ & $\begin{array}{l}978,941.220 \\
978,851.624 \\
979,160.532 \\
979,130.949 \\
979,030.798\end{array}$ & $\begin{array}{l}.050 \\
.080 \\
.080 \\
.080 \\
.080\end{array}$ \\
\hline $\begin{array}{l}K G N-11 \\
K G N-12 \\
K G N-13 \\
K G N-14 \\
K G N-15\end{array}$ & $\begin{array}{l}27^{\circ} 30.85^{\prime} \\
24^{\circ} 34.75^{\prime} \\
23^{\circ} 49.88^{\prime} \\
22^{\circ} 26.53^{\prime} \\
21^{\circ} 20.98^{\prime}\end{array}$ & $\begin{array}{l}38^{\circ} 35.45^{\prime} \\
39^{\circ} 47.00^{\prime} \\
42^{\circ} 53.13^{\prime} \\
41^{\circ} 46.30^{\prime} \\
40^{\circ} 16.10^{\prime}\end{array}$ & $\begin{array}{r}1,137.35 \\
793.60 \\
1,041.40 \\
982.29 \\
2,177.30\end{array}$ & $\begin{array}{l}978,807.165 \\
978,686.155 \\
978,605.712 \\
978,518.026 \\
978,171.202\end{array}$ & $\begin{array}{l}.080 \\
.080 \\
.080 \\
.080 \\
.080\end{array}$ \\
\hline $\begin{array}{l}K G N-16 \\
K G N-17 \\
K G N-18 \\
K G N-19 \\
K G N-20\end{array}$ & $\begin{array}{l}18^{\circ} 17.58^{\prime} \\
19^{\circ} 38.12^{\prime} \\
20^{\circ} 16.72^{\prime} \\
21^{\circ} 52.44^{\prime} \\
24^{\circ} 37.50^{\prime}\end{array}$ & $\begin{array}{l}42^{\circ} 40.30^{\prime} \\
43^{\circ} 15.27^{\prime} \\
45^{\circ} 08.65^{\prime} \\
46^{\circ} 27.01^{\prime} \\
46^{\circ} 47.20^{\prime}\end{array}$ & $\begin{array}{r}2,112.41 \\
1,232.40 \\
922.00 \\
578.78 \\
639.61\end{array}$ & $\begin{array}{l}978,002.230 \\
978,259.829 \\
978,362.151 \\
978,580.632 \\
978,769.310\end{array}$ & $\begin{array}{l}.028 \\
.022 \\
.080 \\
.080 \\
.080\end{array}$ \\
\hline $\begin{array}{l}K G N-21 \\
K G N-22 \\
K G N-23 \\
K G N-24 \\
K G N-25\end{array}$ & $\begin{array}{l}24^{\circ} 53.88^{\prime} \\
26^{\circ} 05.77^{\prime} \\
25^{\circ} 04.07^{\prime} \\
27^{\circ} 31.40^{\prime} \\
27^{\circ} 44.58^{\prime}\end{array}$ & $\begin{array}{l}44^{\circ} 43.13^{\prime} \\
43^{\circ} 59.80^{\prime} \\
40^{\circ} 43.57^{\prime} \\
41^{\circ} 43.65^{\prime} \\
42^{\circ} 54.18^{\prime}\end{array}$ & $\begin{array}{r}779.36 \\
695.50 \\
1,021.20 \\
1,140.60 \\
743.17\end{array}$ & $\begin{array}{l}978,734.855 \\
978,830.525 \\
978,670.109 \\
978,839.919 \\
978,963.990\end{array}$ & $\begin{array}{l}.080 \\
.080 \\
.080 \\
.080 \\
.080\end{array}$ \\
\hline $\begin{array}{l}K G N-26 \\
K G N-27 \\
K G N-28 \\
K G N-31 \\
K G N-32\end{array}$ & $\begin{array}{l}29^{\circ} 37.12^{\prime} \\
30^{\circ} 56.78^{\prime} \\
29^{\circ} 46.15^{\prime} \\
20^{\circ} 39.94^{\prime} \\
17^{\circ} 49.00\end{array}$ & $\begin{array}{l}43^{\circ} 31.92^{\prime} \\
40^{\circ} 58.98^{\prime} \\
38^{\circ} 10.83^{\prime} \\
41^{\circ} 59.35 \\
44^{\circ} 26.95^{\prime}\end{array}$ & $\begin{array}{r}454.70 \\
597.39 \\
754.70 \\
1,364.20 \\
1,212.33\end{array}$ & $\begin{array}{l}979,161.532 \\
978,206.107 \\
979,085.240 \\
978,311.000 \\
978,148.363\end{array}$ & $\begin{array}{l}.080 \\
.080 \\
.080 \\
.080 \\
.080\end{array}$ \\
\hline $\begin{array}{l}\text { KGN-33 } \\
\text { KGN-34 } \\
K G N-37 \\
K G N-38 \\
K G N-39\end{array}$ & $\begin{array}{l}21^{\circ} 56.25^{\prime} \\
23^{\circ} 14.72^{\prime} \\
25^{\circ} 14.18^{\prime} \\
26^{\circ} 29.00^{\prime} \\
26^{\circ} 59.95^{\prime}\end{array}$ & $\begin{array}{l}43^{\circ} 32.77^{\prime} \\
44^{\circ} 36.00^{\prime} \\
48^{\circ} 32.85^{\prime} \\
47^{\circ} 20.00^{\prime} \\
44^{\circ} 58.52^{\prime}\end{array}$ & $\begin{array}{r}1,097.50 \\
1,363.00 \\
363.31 \\
424.16 \\
599.60\end{array}$ & $\begin{array}{l}978,434.961 \\
978,465.884 \\
978,847.232 \\
978,914.630 \\
979,932.797\end{array}$ & $\begin{array}{l}.080 \\
.080 \\
.080 \\
.080 \\
.080\end{array}$ \\
\hline $\begin{array}{l}K G N-40 \\
K G N-41 \\
K G N-42 \\
K G N-43 \\
K G N-45\end{array}$ & $\begin{array}{l}28^{\circ} 32.20^{\prime} \\
25^{\circ} 44.17^{\prime} \\
23^{\circ} 30.08^{\prime} \\
26^{\circ} 19.70^{\prime} \\
31^{\circ} 19.93^{\prime}\end{array}$ & $\begin{array}{l}45^{\circ} 34.63^{\prime} \\
42^{\circ} 55.57^{\prime} \\
40^{\circ} 51.60^{\prime} \\
39^{\circ} 19.60^{\prime} \\
37^{\circ} 19.37^{\prime}\end{array}$ & $\begin{array}{r}377.19 \\
743.50 \\
1,231.00 \\
1,276.20 \\
530.39\end{array}$ & $\begin{array}{l}979,097.926 \\
978,779.694 \\
978,511.183 \\
978,693.748 \\
979,258.212\end{array}$ & $\begin{array}{l}.080 \\
.080 \\
.080 \\
.080 \\
.080\end{array}$ \\
\hline $\begin{array}{l}\text { KGN-46 } \\
\text { KGN-47 }\end{array}$ & $\begin{array}{l}32^{\circ} 09.33^{\prime} \\
17^{\circ} 41.67^{\prime}\end{array}$ & $\begin{array}{l}39^{\circ} 12.08^{\prime} \\
42^{\circ} 17.60^{\prime}\end{array}$ & $\begin{array}{r}948.38 \\
135.6\end{array}$ & $\begin{array}{l}979,249.398 \\
978,485.329\end{array}$ & $\begin{array}{l}.080 \\
.030\end{array}$ \\
\hline
\end{tabular}


observed gravity differences between the G330 determinations and those of Flanigan and Akhrass (192, "unfuy yielded a mean calibration factor of 1.000414 for the gravity differences reported by Flanigan and Akhrass (1912, devere). Station KGN-3 was found to be unacceptably discrepant, and was omitted from the regression calculation. The final adjustment equation used to apply the calibration factor to the gravity differences and bring the Flanigan and Akhrass data to the IGSN7I datum is OG(IGSN71) = (OG IRI38 - JED BASE) (1.000414) + 978,741.008 where OG(IRI38) and JED BASE are the observed gravity values reported by Flanigan and Akhrass(1912, principal factors for the Flanigan and Akhrass stations on the IGSN71 datum are given in table 5 . Stations $\mathrm{KGN}-5$ and $\mathrm{KGN}-6$ have been subsequently adjusted by new ties using a Lacoste-Romberg gravimeter calibrated on the Jiddah - At Ta'if calibration line (J.Boureau, ARGAS, oral communication, 1982). Stations KGN-2, KGN-3, KGN-16, and KGN-17 have been adjusted from recent work (Gettings, 1983).

Gravimeters G506 and G511 were calibrated on part of the North American Gravity Calibration Range, upon delivery from the manufacturers, in August, 1978. The calibration loops at Mt. Hamilton and Palm Springs, California (Barnes and others, 1969) were used because they are well-established ranges and cover a range of observed gravities which fall in the upper part of the Saudi Arabian range, The Mt. Hamilton loop was run twice and the Palm Springs loop was run once with both gravimeters. Data reduction was carried out by D.F.Barnes, USGS, Menlo Park, California. Both gravimeters showed high drift rates and quite a lot of scatter in the calibration results, which is typical of these meters before the measurement mechanism has had the time to "age". Usually, Lacoste-Romberg gravimeters show a drastic reduction in drift rate, and number and magnitude of tares after a year or so of use. The resulting calibration factors for the three runs were $1.00054 \pm 0.00004$, and $1.00052 \pm 0.00008$ for G506 and G511, respectively. The presently accepted values of 1.00041 \pm 0.00006 , and $1.00044 \pm 0.00005$, respectively, show a significant change in calibration over the two-year interval between calibrations, and presumably reflect the "aging" of the measurement mechanisms.

At the request of the Meteorology Department, Saudi Arabian Airlines, a station was established in the Meteorology Laboratory office, room 110. building 202, at the King Abdul Aziz International Airport, Jiddah. The station is located on the tile floor at the base of a brick column in the west wall of the laboratory, immediately north of the exit door in the southwest corner of the laboratory. Gravimeter G511 was used to make one tie only, and the observed gravity value was computed to be $978,744.57 \pm 0.10 \mathrm{mgal}$. 
Finally, it should be noted that the "Honkasalo Correction" (Honkasalo, 1964) has not been applied to the earth tidal gravity calculations used in the reduction of data reported here. This correction corrects the formulae of Longman (1959) so that the earth tides average zero at every latitude and was accounted for in the drift corrections applied to the gravity differences in the data used here.

\section{SUMMARY}

A first-order gravity base station, USGS $x$, tied to the International Gravity Standardization Net 1971 (IGSN71) via the IGSN7l stations at Khartoum $K$, Port Sudan $K$, and Nairobi $B$, has been established in Jiddah. In the process, the four LacosteRomberg gravimeters used to establish the base station were calibrated to the IGSN7I scale (mgal). The Jiddah USGS $x$ observed gravity value is $978,738.973 \mathrm{mgal}$ with a standard deviation of $0.024 \mathrm{mgal}$ and a standard error of the mean of $0.003 \mathrm{mgal}$ based on 60 out of 64 ties. Based on USGS quality criteria, the station is first-order and has a minimum accuracy of $\pm 0.020 \mathrm{mgal}$.

A gravimeter calibration line consisting of USGS $x$ and five stations along the highway from Jiddah to the top of the escarpment near At $\mathrm{Ta}$ if has been established with a total of 20 loops, in five runs, using the same four meters. All the stations are of second-order or better quality, and the data have been used to refine the calibration factors for the four LacosteRomberg gravimeters G328, G330, G506, and G511. The calibration line has a gravity range of approximately 504 mgal, in the central part of the range of observed gravities in Saudi Arabia. Use of the calibration for all gravimeters used in Saudi Arabia will ensure that the resulting gravity data are on the IGSN71 datum, and that all gravimeters have the same scale.

The gravity base station network previously reported by Flanigan and Akhrass(1972, nyal) has been adjusted to the IGSN71 datum, and the adjusted values for stations not subsequently retied are of third-order quality.

Station descriptions and principal facts for the relevant base stations have been compiled to facilitate the use of the gravity base stations in future surveys. 


\section{REPERENCES CITED}

Barnes, D.F., Oliver, H.W., and Robbins, S.L., 1969, Standardization of gravimeter calibrations in the Geological Survey: EOS, Transaction of the American Geophysical Union, vol. 50, p. 526-527.

Bevington, P.R., 1969, Data reduction and error analysis for the physical sciences: New York, McGraw-Hill, 336 p.

Gettings, M.E., 1983, A simple Bouguer gravity anomaly map of southwestern Saudi Arabia and an initial interpretation: Saudi Arabian Deputy Ministry for Mineral Resources OpenFile Report USGS-OF-03-94, 63 p., 6 plates, 7 figs., 4 tables, 1 app. ; also, 1983, U.S. Geological Survey Open-File Report 83-789.

Ghalayini, A.K., 1958, Gravity measurements (in) Saudi Arabia: Saudi Arabian Directorate General of Mineral Resources OpenFile Report 82, 22 p.

Hamilton, A.C., and Brule, B.G., 1967, Vibration-induced drift in La Coste and Romberg geodetic gravimeters: Journal of Geophysical Research, v. 72, no. 8, p. 2187-2197.

Honkasalo, T., 1964, On the tidal gravity correction: Bollettina Geofisica Teorica ed Applicata, v. 6, no. 21, p. 34-36.

Longman, I.M., 1959, Formulas for computing the tidal accelerations due to the moon and the sun: Journal of Geophysical Research, v. 64, p. 2351-2355.

Morelli, C., Gantar, C., Honkasalo, T., McConnell, R.K., Tanner, J.G., Szabo, B., Uotila, U., Whalen, C.T., 1971, The international gravity standardization net: International Association of Geodesy, Special Publication No. 4, 194 p.

Robbins, S.L., 1971, USGS gravity data in California, Part XXII --Base station network used in east-central California: AMS Project Order No. 3-68, 23 p., 6 figs., 1 pl., 1 appendix. 
Appendix 1.-Summary results for the gravimeter calibration and base tie loop from Jiddah to three IGSN71 stations. Column heading explanation: elaps. time, elapsed time in days since reading of base $\mathrm{Bl}$; mgal-dif, difference in mgal between station and base; obs. grav, observed gravity in mgals measured; diff, mgal difference between IGSN71 observed gravity at the station and the measured observed gravity; succ. diff, successive difference of mgal differences for sequential stations in the table

CALIEFATIOH RESULTS FOF METEF 0328 FOF CALIBFATION FUN BETWEEN 0001 HFS ON (IIM/Y) $20 / 6 / 80$ ANI 2359 HFS ON $24 / 6 / 80$

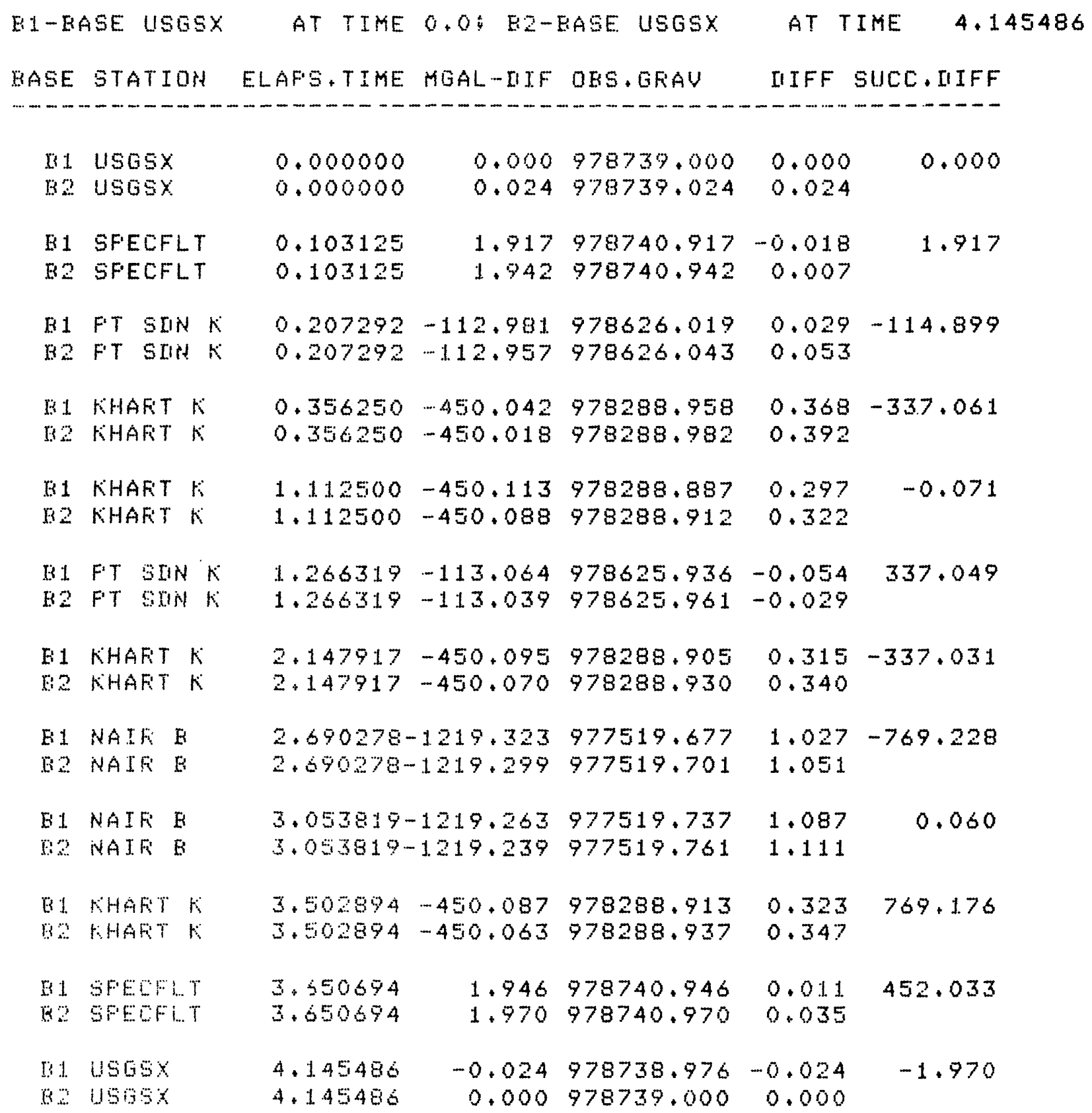


Appendix 1.-Summary results for the gravimeter calibration and base tie loop from Jiddah to three IGSN71 stations. Column heading explanation: elaps. time, elapsed time in days since reading of base $\mathrm{Bl}$; mgal-dif, difference in mgal between station and base; obs. grav, observed gravity in mgals measured; diff, mgal difference between IGSN71 observed gravity at the station and the measured observed gravity; succ. diff, successive difference of mgal differences for sequential stations in the table (Continued)

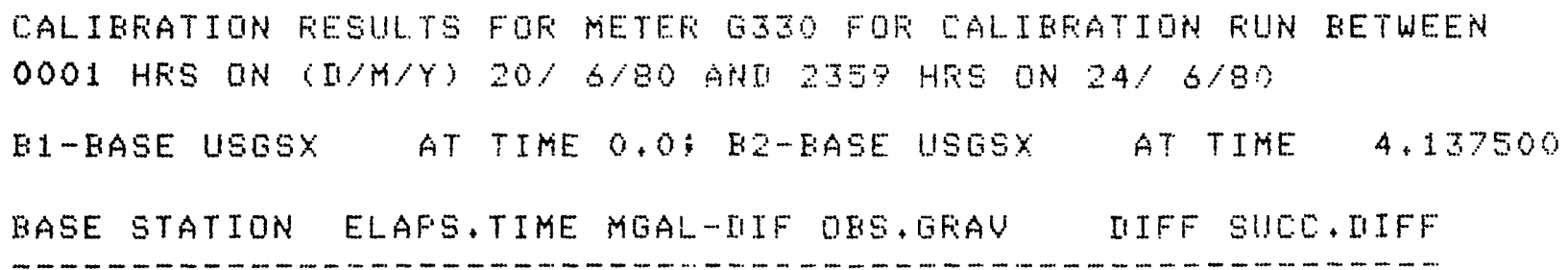

\begin{tabular}{|c|c|c|c|c|c|c|}
\hline $\begin{array}{l}B 1 \\
B 2\end{array}$ & $\begin{array}{l}4565 x \\
4565 x\end{array}$ & $\begin{array}{l}0.000000 \\
0.000000\end{array}$ & $\begin{array}{r}0.000 \\
-0.101\end{array}$ & $\begin{array}{l}978739.000 \\
978738.899\end{array}$ & $\begin{array}{r}0.000 \\
-0.101\end{array}$ & 0.000 \\
\hline $\begin{array}{l}81 \\
82\end{array}$ & $\begin{array}{l}\text { SFECFLT } \\
\text { SFECFLT }\end{array}$ & $\begin{array}{l}0.101736 \\
0.101736\end{array}$ & $\begin{array}{l}1.894 \\
1.793\end{array}$ & $\begin{array}{l}978740.894 \\
978740.793\end{array}$ & $\begin{array}{l}-0.041 \\
-0.142\end{array}$ & 1.894 \\
\hline 1 & $\begin{array}{l}\text { FT SIIN K } \\
\text { FT SIIN K }\end{array}$ & $\begin{array}{l}0.208681 \\
0.208681\end{array}$ & $\begin{array}{l}-112.977 \\
-113.078\end{array}$ & $\begin{array}{l}978626.023 \\
978625.922\end{array}$ & $\begin{array}{r}0.033 \\
-0.068\end{array}$ & -114.871 \\
\hline 1 & $\begin{array}{l}\text { KHAFT } K \\
\text { KHAFT } K\end{array}$ & $\begin{array}{l}0.348264 \\
0.348264\end{array}$ & $\begin{array}{l}-450 \cdot 300 \\
-450.401\end{array}$ & $\begin{array}{l}978288.700 \\
978288.599\end{array}$ & $\begin{array}{l}0.110 \\
0.009\end{array}$ & -337.323 \\
\hline $\begin{array}{l}1 \\
2\end{array}$ & $\begin{array}{l}\text { KHAFT K } \\
\text { KHAKT K }\end{array}$ & $\begin{array}{l}1.104861 \\
1+104861\end{array}$ & $\begin{array}{l}-450.348 \\
-450.448\end{array}$ & $\begin{array}{l}978288.652 \\
978288.552\end{array}$ & $\begin{array}{r}0.062 \\
-0.038\end{array}$ & -0.048 \\
\hline$\frac{1}{2}$ & $\begin{array}{l}\text { FT SIN } K \\
\text { FT SIN } K\end{array}$ & $\begin{array}{l}1+257639 \\
1+257639\end{array}$ & $\begin{array}{l}-112.926 \\
-113.027\end{array}$ & $\begin{array}{l}978626.074 \\
978625.973\end{array}$ & $\begin{array}{r}0.084 \\
-0.017\end{array}$ & 337 \\
\hline$\frac{1}{2}$ & $\begin{array}{l}\text { KHAFT } K \\
\text { KHAFT } K\end{array}$ & $\begin{array}{l}2+140278 \\
2+140278\end{array}$ & $\begin{array}{l}-450.299 \\
-450.399\end{array}$ & $\begin{array}{l}978288 \cdot 701 \\
978288 \cdot 601\end{array}$ & $\begin{array}{l}0.111 \\
0.011\end{array}$ & $-337+372$ \\
\hline $\begin{array}{l}1 \\
2\end{array}$ & $\begin{array}{ll}\text { NAIF } & \mathrm{B} \\
\text { NAIF } & \mathrm{B}\end{array}$ & $\begin{array}{l}2.690972 \ldots \\
2.690972-\end{array}$ & $\begin{array}{l}1219.956 \\
1220.057\end{array}$ & $\begin{array}{l}977519.044 \\
977518.943\end{array}$ & $\begin{array}{l}0.394 \\
0.293\end{array}$ & -769.657 \\
\hline $\begin{array}{l}1 . \\
2\end{array}$ & $\begin{array}{ll}\text { NAIF } & B \\
\text { NAIK } & B\end{array}$ & $\begin{array}{l}3.045833- \\
3.045833\end{array}$ & $\begin{array}{l}1219.898 \\
1219.998\end{array}$ & $\begin{array}{l}977519.1 .02 \\
977519.002\end{array}$ & $\begin{array}{l}0.452 \\
0.352\end{array}$ & .059 \\
\hline 1 & $\begin{array}{l}\text { KHAFT K } \\
\text { KHART K }\end{array}$ & $\begin{array}{l}3.502431 \\
3.502431\end{array}$ & $\begin{array}{l}-450 \cdot 284 \\
-450 \cdot 385\end{array}$ & $\begin{array}{l}978288+716 \\
978288 \cdot 615\end{array}$ & $\begin{array}{l}0.126 \\
0.025\end{array}$ & $769+614$ \\
\hline 1 & $\begin{array}{l}\text { SFECFLT } \\
\text { SFECFLT }\end{array}$ & $\begin{array}{l}3.642708 \\
3.642708\end{array}$ & $\begin{array}{l}1.951 \\
1.850\end{array}$ & $\begin{array}{l}978740.951 \\
978740.850\end{array}$ & $\begin{array}{r}0.016 \\
-0.085\end{array}$ & 452.2 \\
\hline 11 & $\begin{array}{l}4569 x \\
4569 x\end{array}$ & $\begin{array}{l}4.137500 \\
4.137500\end{array}$ & $\begin{array}{l}0.101 \\
0.000\end{array}$ & $\begin{array}{l}979739.101 \\
978739.000\end{array}$ & $\begin{array}{l}0.101 \\
0.000\end{array}$ & - \\
\hline
\end{tabular}


Appendix 1. -Summary results for the gravimeter calibration and base tie loop from Jiddah to three IGSN7I stations. Column heading explanation: elaps. time, elapsed time in days since reading of base $\mathrm{Bl}$; mgal-dif, difference in mgal between station and base; obs. grav, observed gravity in mgals measured; diff, mgal difference between IGSN7I observed gravity at the station and the measured observed gravity; succ. diff, successive difference of mgal differences for sequential stations in the table (Continued)

CALIBFATION FESULTS FOF METEF GSOS FOF CALIBFATION FUN BETWEEN 0001 HFS ON (I/M/Y) $20 / 6 / 80$ ANI 2359 HES ON $24 / 6 / 80$

B1-BASE USGSX AT TIME 0.0; E2-BASE USGSX AT TIME 4.142014

BASE STATION ELAFS.TIME MGAL-IIF OES.GEAV IIFF SUCC. IIFF

\begin{tabular}{|c|c|c|c|c|c|c|}
\hline $\begin{array}{l}\mathrm{B1} \\
\mathrm{B2}\end{array}$ & $\begin{array}{l}\text { USGSX } \\
\text { USGSX }\end{array}$ & $\begin{array}{l}0.000000 \\
0.000000\end{array}$ & $\begin{array}{r}0.000 \\
-0.265\end{array}$ & $\begin{array}{l}978739.000 \\
978738.735\end{array}$ & $\begin{array}{r}0.000 \\
-0.265\end{array}$ & 0.000 \\
\hline $\begin{array}{l}\mathrm{E1} \\
\mathrm{B2}\end{array}$ & $\begin{array}{l}\text { SFECFLT } \\
\text { SFECFLT }\end{array}$ & $\begin{array}{l}0.099653 \\
0.099653\end{array}$ & $\begin{array}{l}1.968 \\
1.702\end{array}$ & $\begin{array}{l}978740.968 \\
978740.702\end{array}$ & $\begin{array}{r}0.033 \\
-0.233\end{array}$ & 1.968 \\
\hline $\begin{array}{l}\text { E1 } \\
B 2\end{array}$ & $\begin{array}{l}\text { FT SIIt K } \\
\text { FT SIIt K }\end{array}$ & $\begin{array}{l}0.188194 \\
0.188194\end{array}$ & $\begin{array}{l}-112.966 \\
-113.231\end{array}$ & $\begin{array}{l}978626.034 \\
978625.769\end{array}$ & $\begin{array}{r}0.044 \\
\cdots 0.221\end{array}$ & -114.733 \\
\hline $\begin{array}{l}B 1 \\
B 2\end{array}$ & $\begin{array}{l}\text { KHAFT K } \\
\text { KHART KK }\end{array}$ & $\begin{array}{l}0.355208 \\
0.355208\end{array}$ & $\begin{array}{l}-450.212 \\
-450.477\end{array}$ & $\begin{array}{l}978288+788 \\
978286+523\end{array}$ & $\begin{array}{r}0.198 \\
-0.067\end{array}$ & -337.247 \\
\hline $\begin{array}{l}\mathrm{B} 1 \\
\mathrm{~B} 2\end{array}$ & $\begin{array}{l}\text { KHAFT K } \\
\text { KHAFT K }\end{array}$ & $\begin{array}{l}1.096528 \\
1.096528\end{array}$ & $\begin{array}{l}-450.117 \\
-450.383\end{array}$ & $\begin{array}{l}978288.883 \\
978288.617\end{array}$ & $\begin{array}{l}0.293 \\
0.027\end{array}$ & 0.095 \\
\hline $\begin{array}{l}\mathrm{B} 1 \\
\mathrm{~B} 2\end{array}$ & $\begin{array}{l}\text { FT SIIN } k \\
\text { FT SIIN }\end{array}$ & $\begin{array}{l}1.260764 \\
1.260764\end{array}$ & $\begin{array}{l}-112,886 \\
-113.152\end{array}$ & $\begin{array}{l}978626.114 \\
978625.848\end{array}$ & $\begin{array}{r}0.124 \\
-0.142\end{array}$ & 337.231 \\
\hline $\begin{array}{l}\mathrm{B1} \\
\mathrm{B} 2\end{array}$ & $\begin{array}{l}\text { KHAFT } K \\
\text { KHAFT } K\end{array}$ & $\begin{array}{l}2.146528 \\
2.146528\end{array}$ & $\begin{array}{l}-450.034 \\
-450.300\end{array}$ & $\begin{array}{l}978288 \cdot 966 \\
978288 \cdot 700\end{array}$ & $\begin{array}{l}0.376 \\
0.110\end{array}$ & $-337+148$ \\
\hline $\begin{array}{l}\mathrm{B1} \\
\mathrm{B} 2\end{array}$ & $\begin{array}{ll}\text { NAIF } & \mathrm{E} \\
\text { NAIF } & \mathrm{E}\end{array}$ & $\begin{array}{l}2.711458 \\
2.711458\end{array}$ & $\begin{array}{l}-1219.635 \\
-1219.900\end{array}$ & $\begin{array}{l}977519.365 \\
977519.100\end{array}$ & $\begin{array}{l}0.715 \\
0.450\end{array}$ & -769.601 \\
\hline $\begin{array}{l}\text { B1 } \\
B 2\end{array}$ & $\begin{array}{ll}\text { NAIF } & B \\
\text { NAIF } & B\end{array}$ & $\begin{array}{l}3.061458 \\
3.061458\end{array}$ & $\begin{array}{l}-1219.680 \\
-1219.946\end{array}$ & $\begin{array}{l}977519.320 \\
977519.054\end{array}$ & $\begin{array}{l}0.670 \\
0.404\end{array}$ & -0.045 \\
\hline $\begin{array}{l}\mathrm{B1} \\
\mathrm{B2}\end{array}$ & $\begin{array}{l}\text { KHAFT K } \\
\text { KHAFT K }\end{array}$ & $\begin{array}{l}3.484028 \\
3.484028\end{array}$ & $\begin{array}{l}-449.963 \\
-450 \cdot 228\end{array}$ & $\begin{array}{l}978289.037 \\
978288.772\end{array}$ & $\begin{array}{l}0.447 \\
0.182\end{array}$ & $769+718$ \\
\hline $\begin{array}{l}B 1 \\
B 2\end{array}$ & $\begin{array}{l}\text { SFECFLT } \\
\text { SFECFLT }\end{array}$ & $\begin{array}{l}3.646528 \\
3.646528\end{array}$ & $\begin{array}{l}2.179 \\
1.914\end{array}$ & $\begin{array}{l}978741.179 \\
978740.914\end{array}$ & $\begin{array}{r}0.244 \\
-0.021\end{array}$ & $452+142$ \\
\hline $\begin{array}{l}\text { B1 } \\
\text { B2 }\end{array}$ & $\begin{array}{l}\operatorname{USGSX} \\
\operatorname{USGSx}\end{array}$ & $\begin{array}{l}4.142014 \\
4.142014\end{array}$ & $\begin{array}{l}0.265 \\
0.000\end{array}$ & $\begin{array}{l}978739.265 \\
978739.000\end{array}$ & $\begin{array}{l}0+265 \\
0+000\end{array}$ & $-1,714$ \\
\hline
\end{tabular}


Appendix 1.-Summary results for the gravimeter calibration and base tie loop from Jiddah to three IGSN71 stations. Column heading explanation: elaps. time, elapsed time in days since reading of base $\mathrm{Bl}$; mgal-dif, difference in mgal between station and base; obs. grav, observed gravity in mgals measured; diff, mgal difference between IGSN71 observed gravity at the station and the measured observed gravity; succ. diff, successive difference of mgal differences for sequential stations in the table (Continued)

CALIEFATTOA FESULTS FUR METEF GS11 FUF CALTBRATIOH RUN BETHEEN 0001 HRS ON (I/M/Y) $20 / 6 / 80$ ANI 2359 HRS UN $24 / 6 / 80$

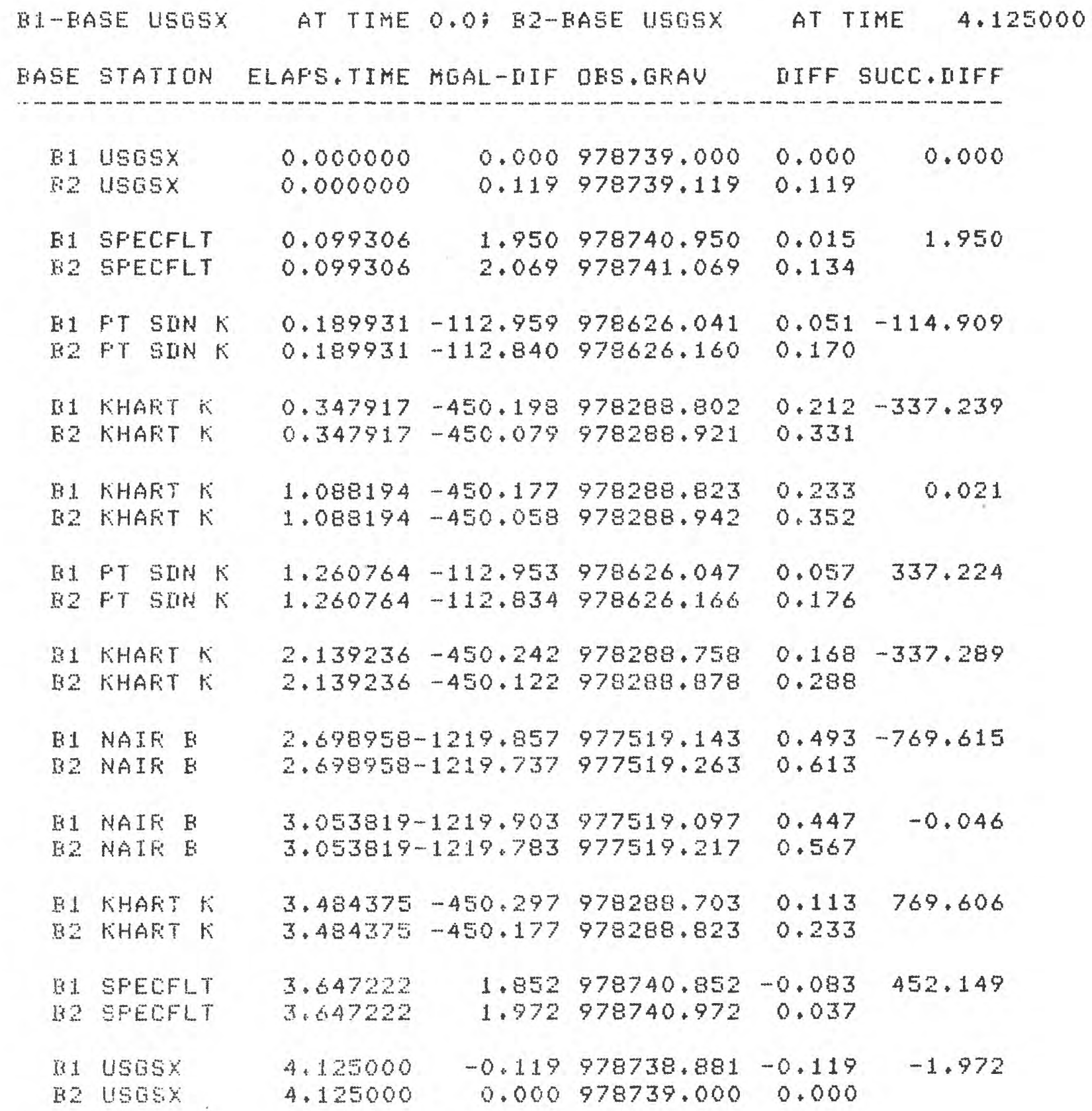



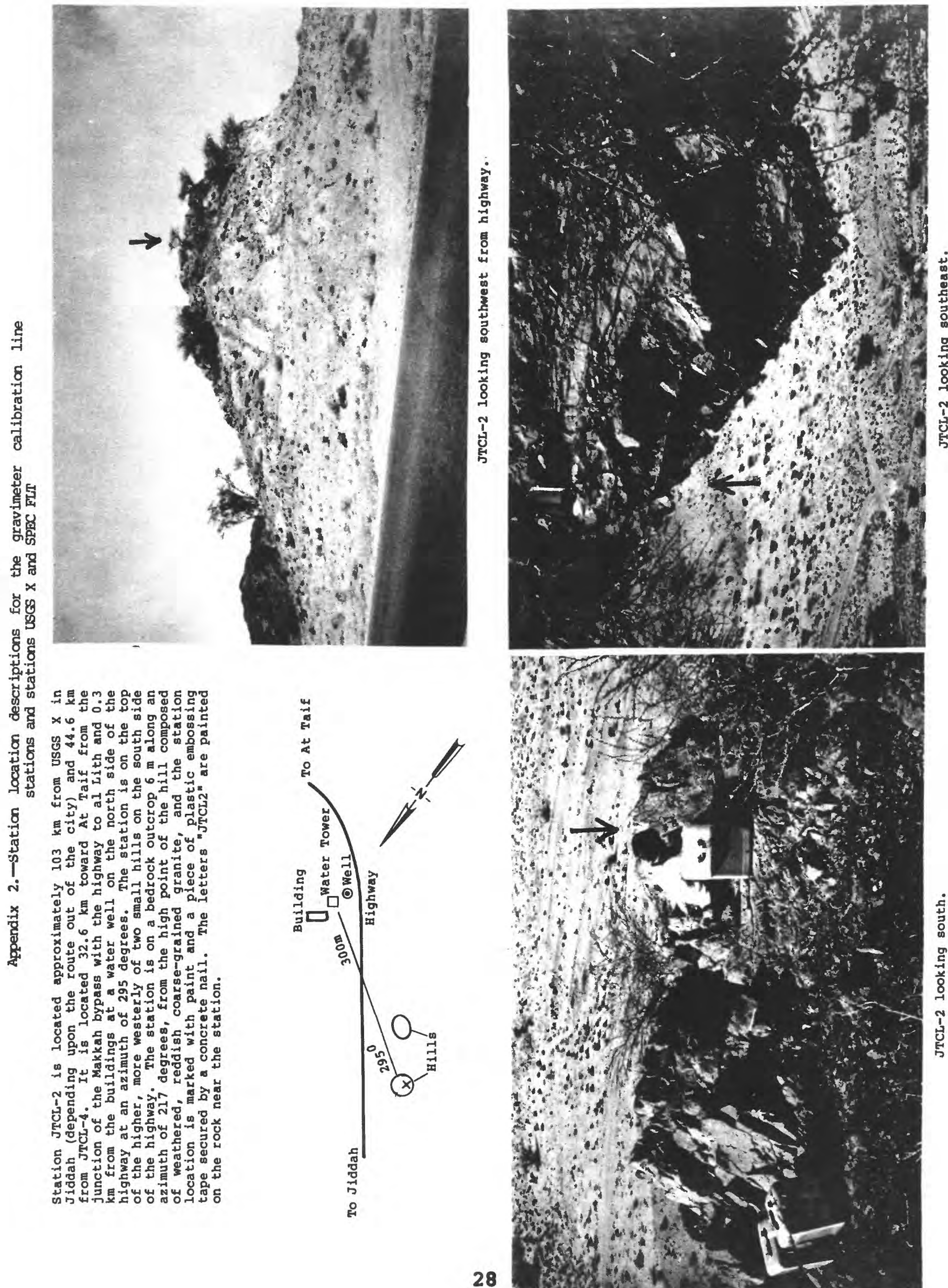


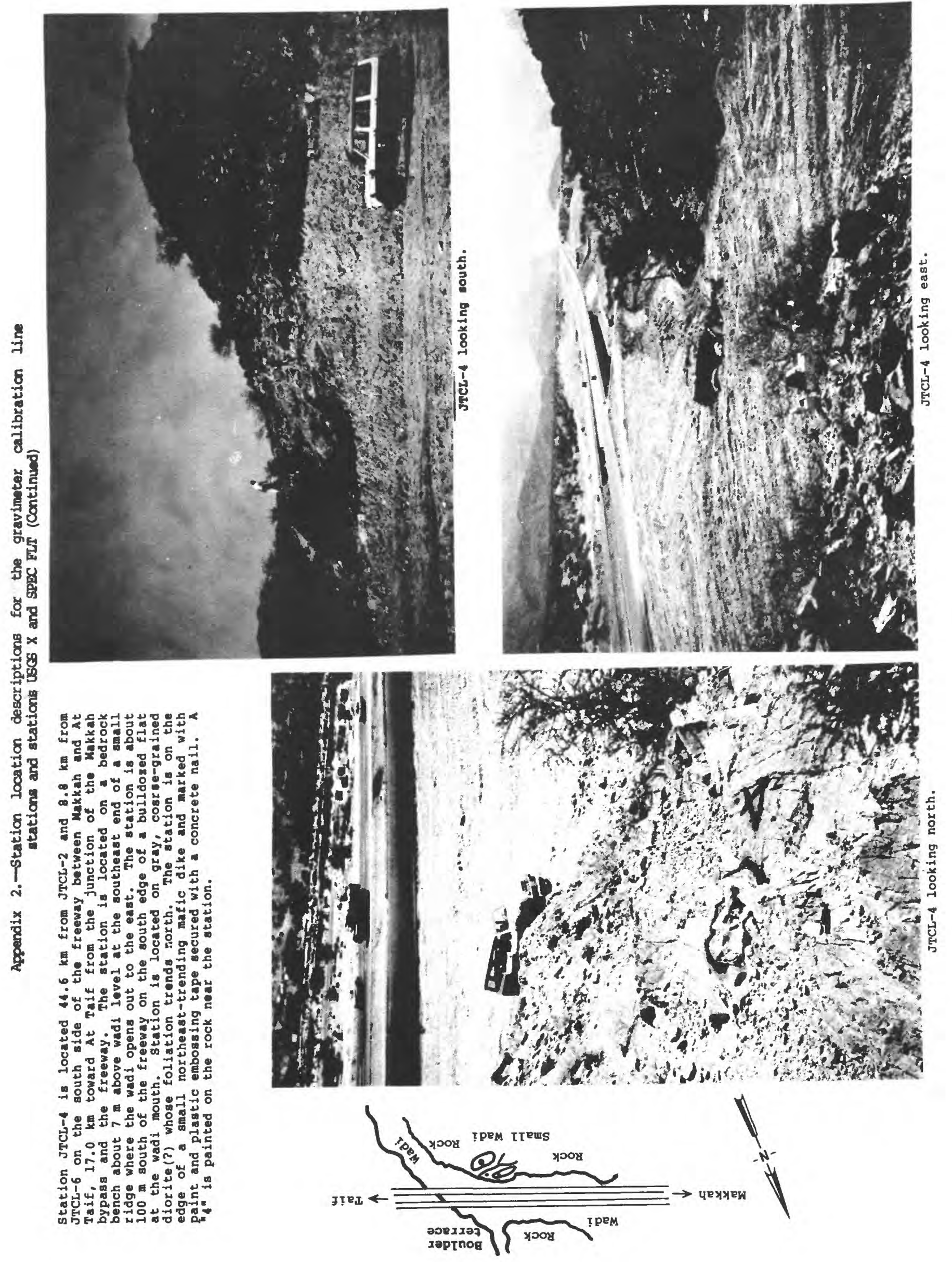



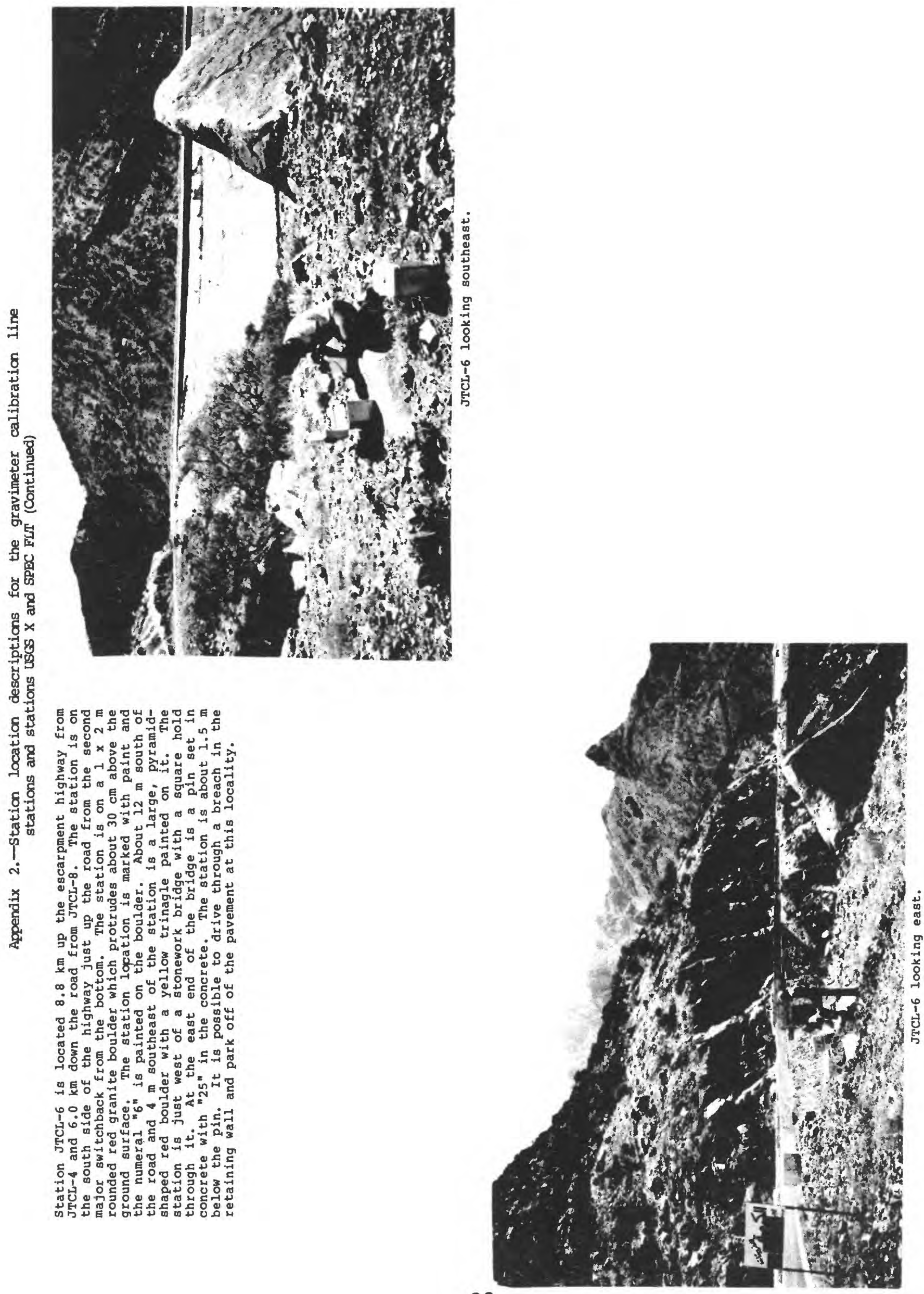

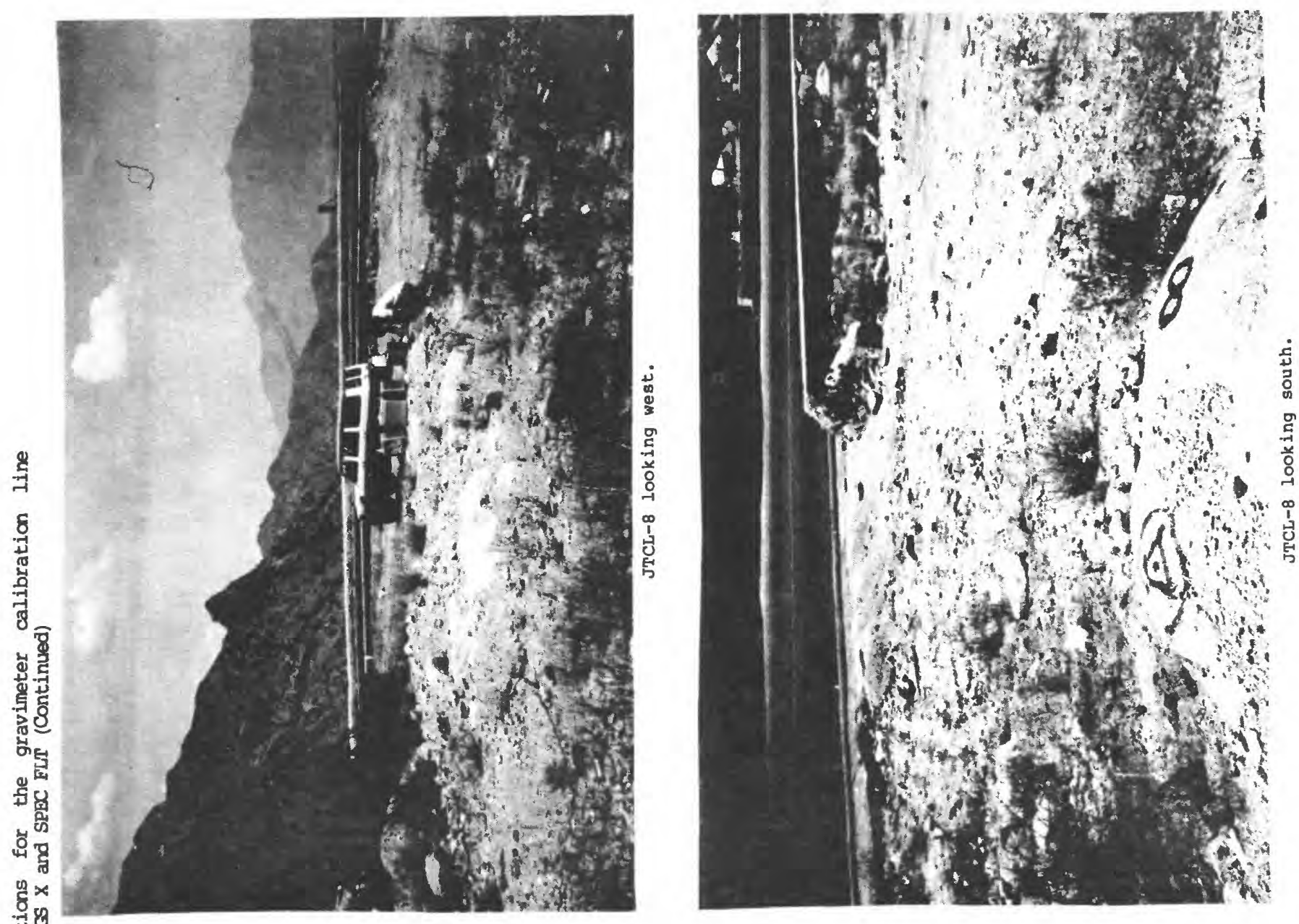

总

句

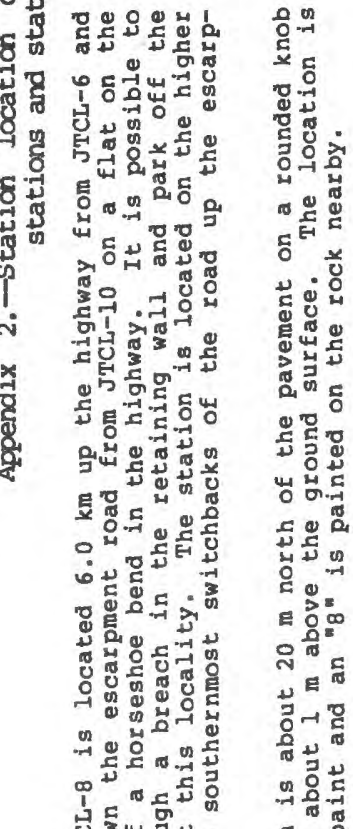

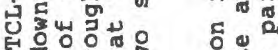

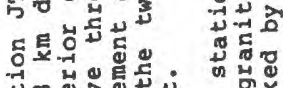

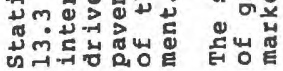

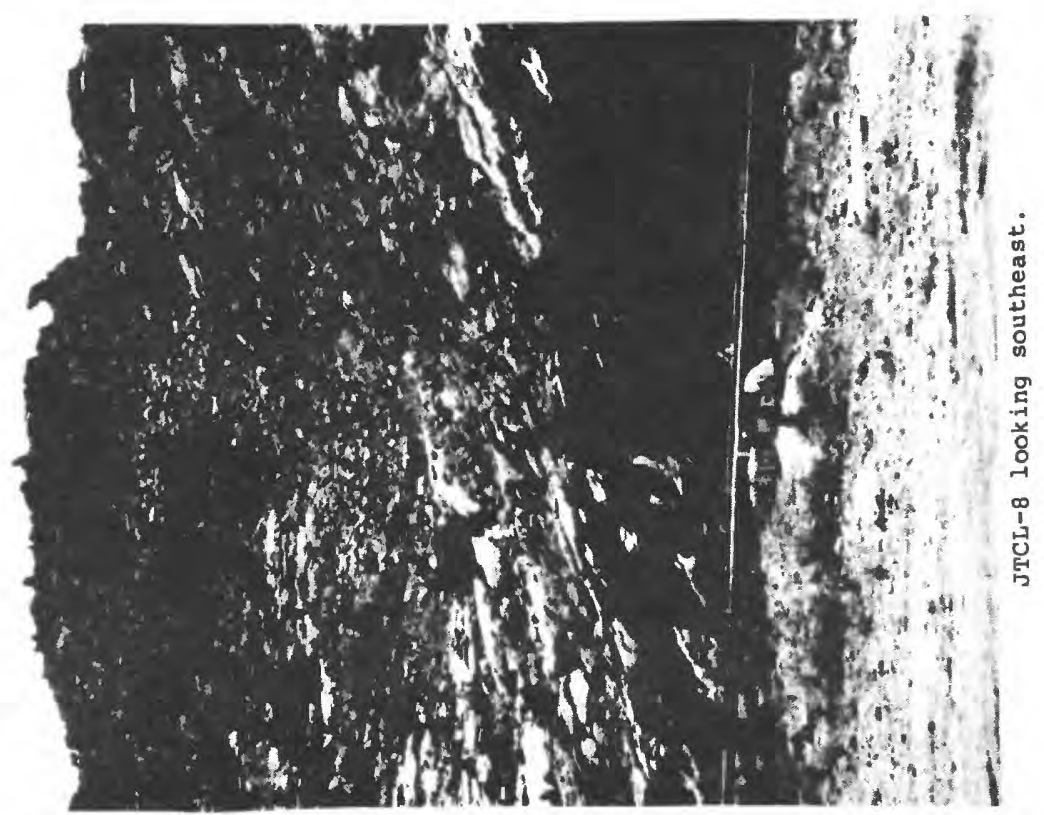



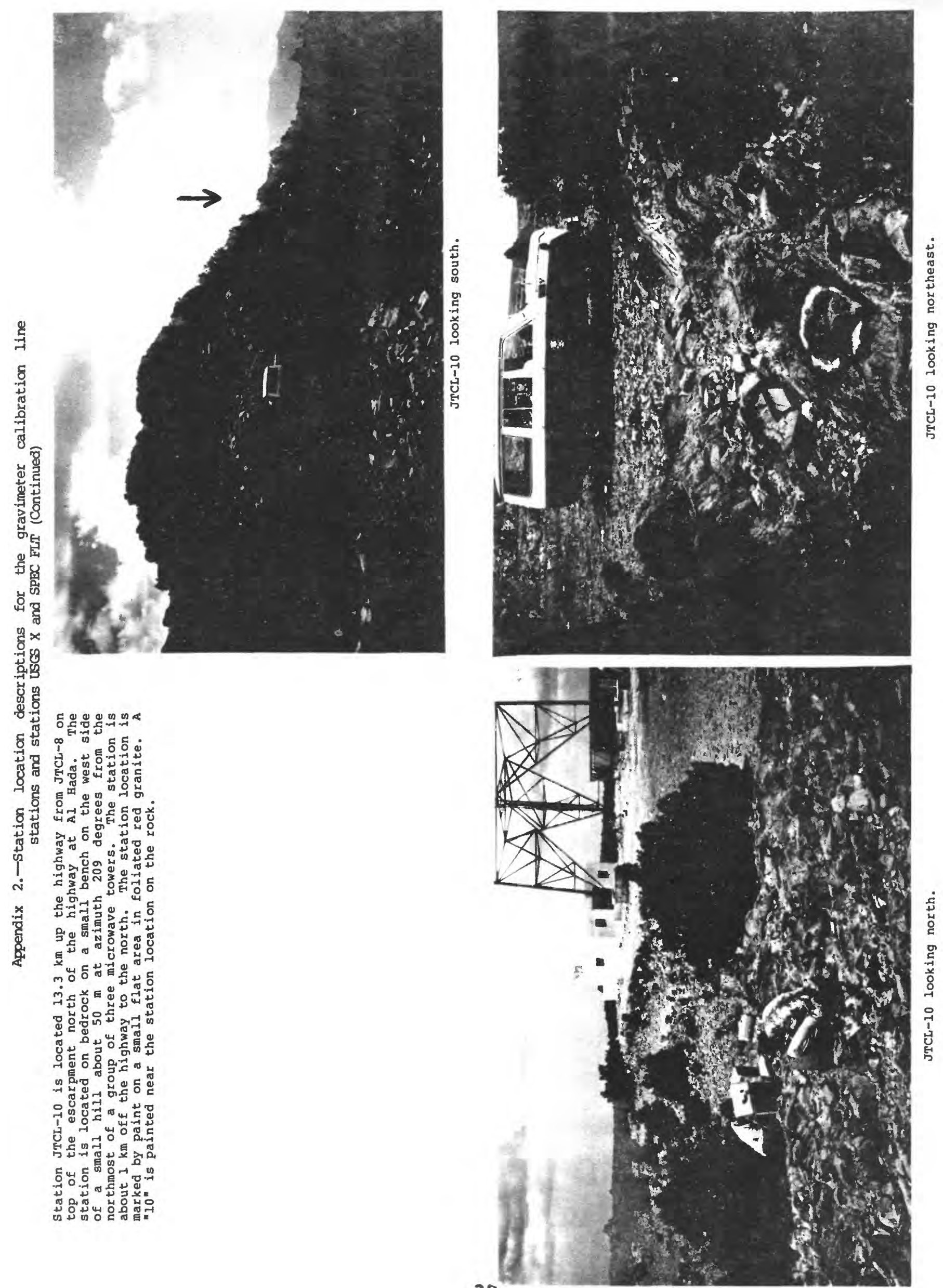


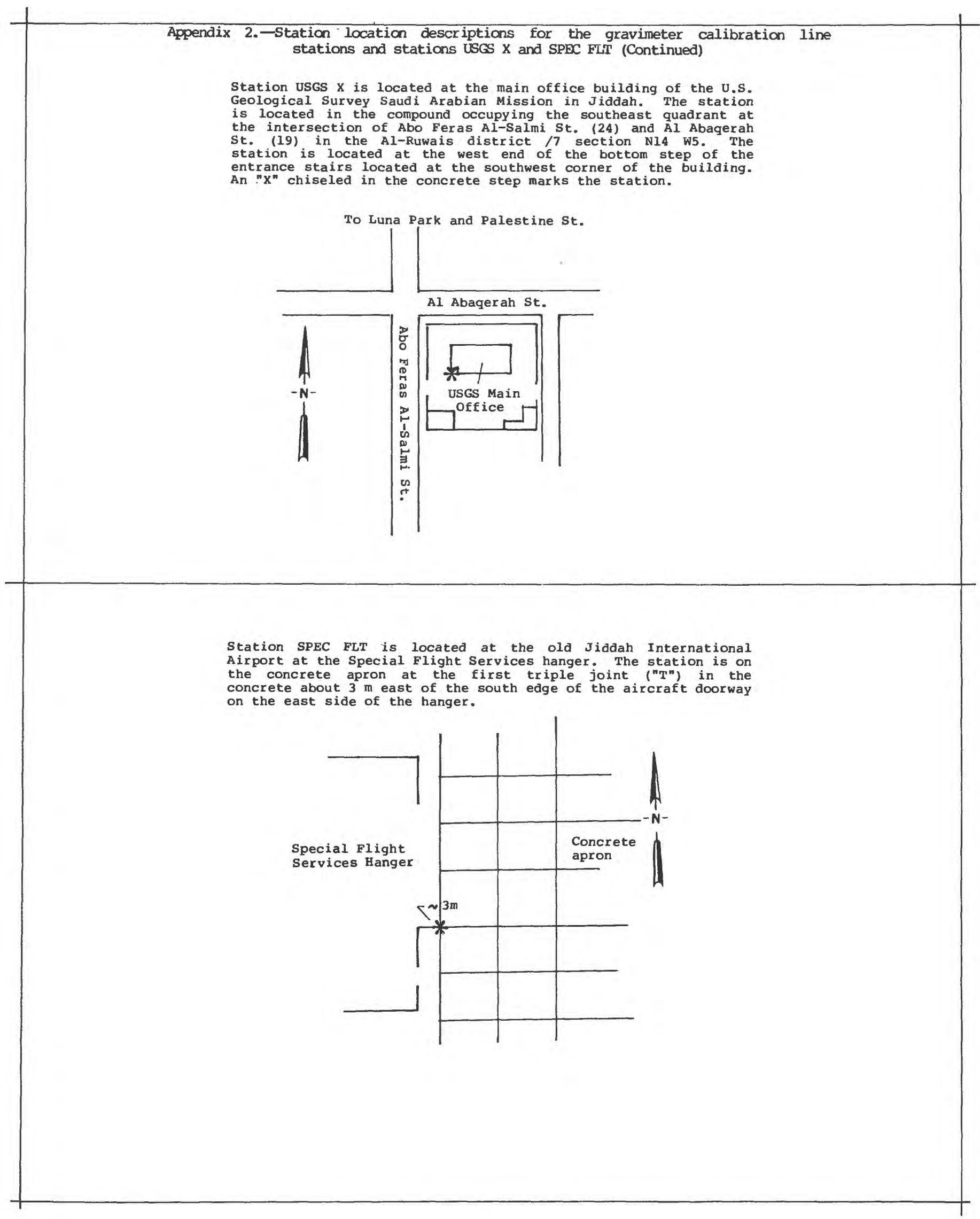

